
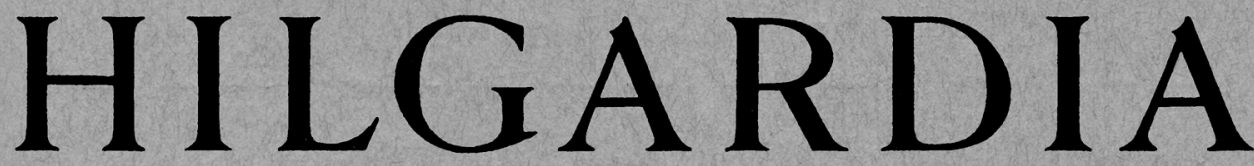

A Journal of Agricultural Science Published by the California Agricultural Experiment Station

CONTENTS

CHARACTERS, DISTRIBUTION, AND FOOD PLANTS OF PHLEPSID LEAFHOPPER VECTORS OF CALIFORNIA ASTER-YELLOWS VIRUS DWIGHT M. DELONG and HENRY H. P. SEVERIN

EVIDENCE OF NONSPECIFIC TRANSMISSION OF CALIFORNIA ASTER-YELLOWS VIRUS BY LEAFHOPPERS

HENRY H. P. SEVERIN

UNIVERSITY OF CALIFORNIA · BERKELEY, CALIFORNIA 
EVIDENCE OF NONSPECIFIC TRANSMISSION OF CALIFORNIA ASTER-YELLOWS VIRUS BY LEAFHOPPERS

HENRY H. P. SEVERIN 


\section{CON'TEN'TS}

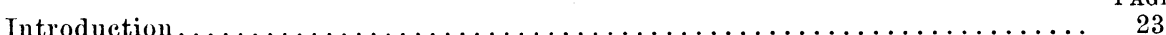

Review of literature on leafhopper-transmitted viruses.............. 24

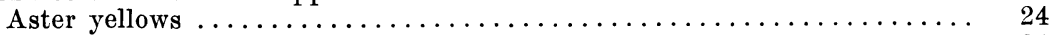

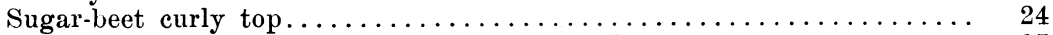

Pierce's disease of grapevine and alfalfa dwarf $\ldots \ldots \ldots \ldots \ldots \ldots \ldots \ldots$

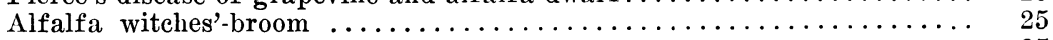

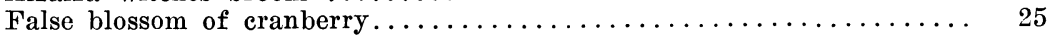

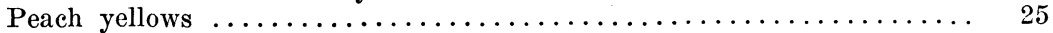

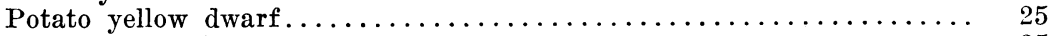

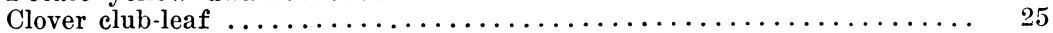

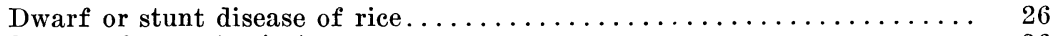

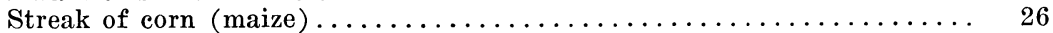

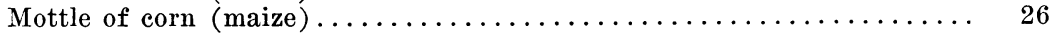

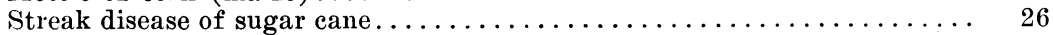

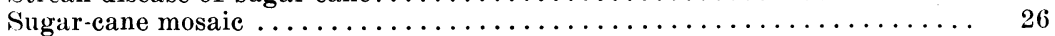

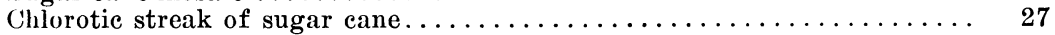

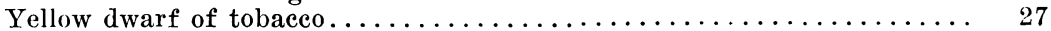

Wallaby ear disease of corn $($ maize $) \ldots \ldots \ldots \ldots \ldots \ldots \ldots \ldots \ldots \ldots \ldots$

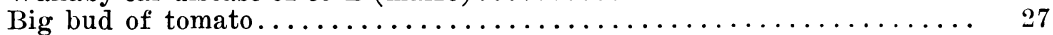

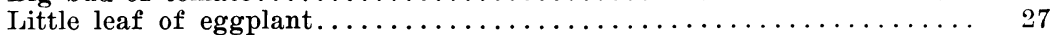

Virus transmission experiments and biology of Texananus lathropi Baker and $T$.

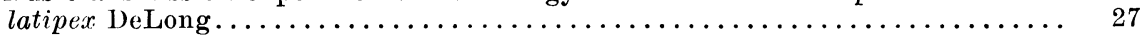

Methods and equipment used with the two vectors.............. 28

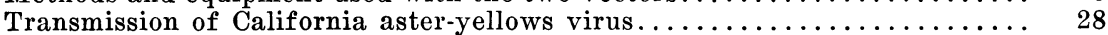

To celery by single males and females................... 28

To celery alternating with asters in daily and weekly inoculations. . . . . 28

To asters alternating with celery in daily and weekly inoculations. . . . . 29

To successive celery alternating with asters, by varying numbers of

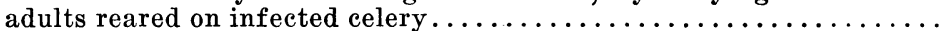

To successive asters alternating with celery, by varying numbers of

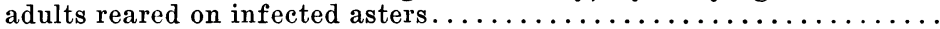

To successive asters by adults reared on infected asters . . . . . . . . . . .

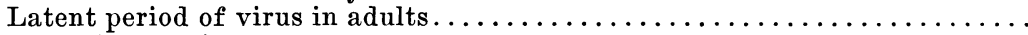

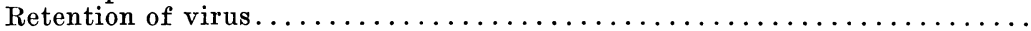

Attempts to transmit viruses of curly top and Pierce's disease of grapevine..

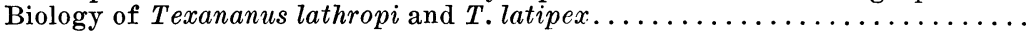

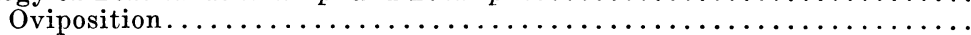

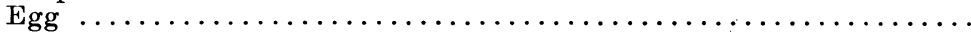

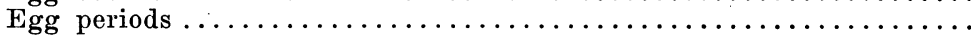

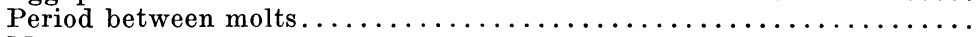

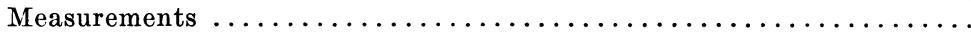

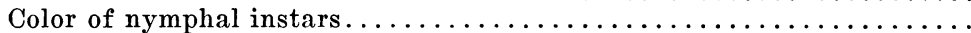

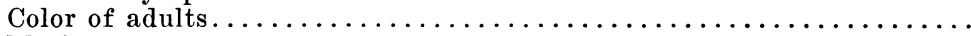

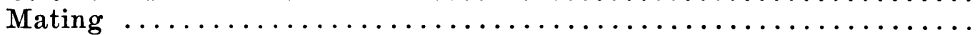

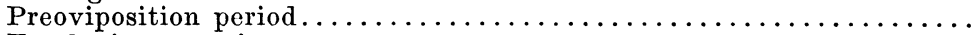

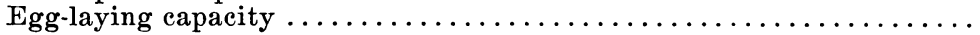

Virus transmission experiments with Texananus spatulatus Van Duzee.........

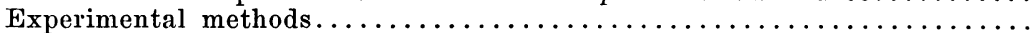

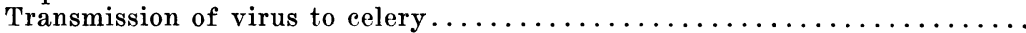

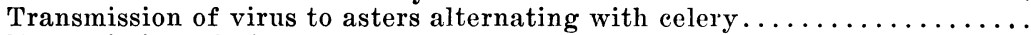

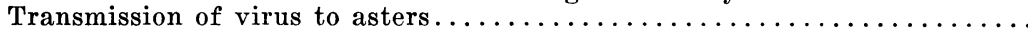

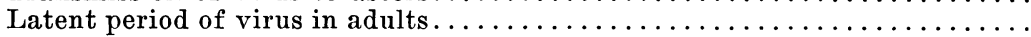

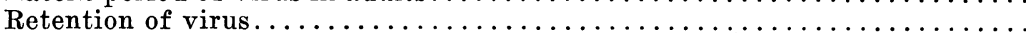

Attempts to transmit viruses of curly top and Pierce's disease of grapevine. .

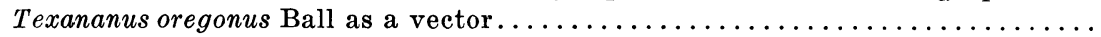

Texananus pergradus DeLong as a vector. . . . . . . . . . . . . . . .

Phlepsius apertinus Osborn and Lathrop as a vector . . . . . . . . . . . . .

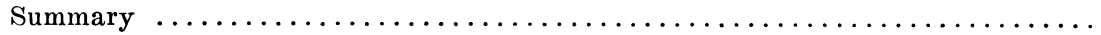

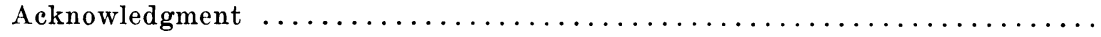

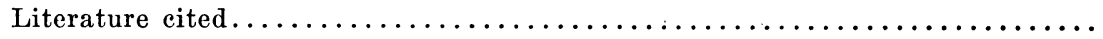




\title{
EVIDENCE OF NONSPECIFIC TRANSMISSION OF CALIFORNIA ASTER-YELLOWS VIRUS BY LEAFHOPPERS ${ }^{2}$
}

\author{
HENRY H. P. SEVERIN ${ }^{2}$
}

\section{INTRODUCTION}

IT MAY BE NECESSARY to define two terms before proceeding with this paper. Specificity is the transmission of a particular virus by one or two closely related species of vectors. "When a virus can be transmitted only by one or two closely related insects and cannot be transmitted artificially (except by grafting) the insect transmission is considered obligatory" (Leach, 1940). ${ }^{8}$

Formerly it was assumed that a specific relation existed between each plant virus and its aphid vector. Among the viruses transmitted by aphids, specificity is now regarded as exceptional rather than common.

In the opinion of Smith (1937), a rather strong point in favor of a specific relationship between leafhopper and virus lies in the fact that certain plant viruses can be transmitted by only one species. Heretofore it has been assumed that the aster-yellows virus could be disseminated only by the aster leafhopper, Macrosteles divisus (Uhl.) $=$ [Cicadula sexnotota (Foll.)], and by no other means except grafting and budding of the plant.

According to Kunkel (1926), the intimate and specific relation existing between the aster-yellows virus and its insect vector is important evidence that the causative entity is biological rather than chemical. Leach (1940) emphasizes the biological, obligatory, and highly specific transmission of viruses by leafhoppers.

There may be some viruses which can be transmitted by only one species of leafhopper. During the past thirty years many species of leafhoppers collected in sugar-beet fields were tested by the author for the transmission of the curlytop virus, but up to the present time no other vector is known except the beet leafhopper, Eutettix tenellus (Baker). According to DeLong (1942), the North American fauna of leafhoppers, north of Mexico, consists of 2,000 species belonging to about $\mathbf{1 5 0}$ genera. No other species of the genus Eutettix has been tested up to the present time. It is naturally assumed that closely related species in the same genus should be tested; on the other hand, species in genera belonging to different subfamilies may be vectors. The sugar beet is an introduced plant, and it may be possible that if leafhoppers are collected on native host plants of the virus, other vectors may be discovered. As will be discussed with aster yellows in this paper, host plants highly susceptible to the virus should be used instead of the sugar beet.

Herewith is presented evidence that the transmission of the aster-yellows virus by six species of phlepsid leafhoppers is not specific. The characters, distribution, and food plants of these six vectors are discussed in a companion paper (DeLong and Severin, 1945). It is evident in the following review of literature that the prevailing concept has in general favored specificity.

${ }^{1}$ Received for publication November 8, 1944.

2 Entomologist in the Experiment Station.

"See "Literature Cited" for complete citation, referred to in the text by author and date of publication. 


\section{REVIEW OF LITERATURE ON LEAFHOPPER-TRANSMITTED VIRUSES}

Aster Yellows.-Severin (1929) reported the transmission of the California aster-yellows virus to celery, lettuce, and ornamental flowering plants by the short-winged aster leafhopper. Severin and Haasis (1934) showed that potato could be experimentally infected with the virus by means of the short-winged aster leafhopper. The virus was not recovered by previously noninfective leafhoppers from infected potato plants, nor from potato tubers obtained from plants showing symptoms of aster yellows. Severin (1940) proved that potato was naturally infected; also that the virus was recovered and transferred to healthy asters by the long-winged aster leafhopper, a race of the same species. Severin (1934) reported the transmission of the California aster-yellows virus by the mountain leafhopper, Colladonus montanus (V.D.) $=($ Thamnotettix montanus V. D.), and by the geminate leafhopper, Idiodonus geminatus (V. D. $)=(T$. geminatus V. D. $)$. In a recent paper, Severin (1942) stated that the mountain and geminate leafhoppers are the most important vectors of the virus to delphinium, and that both species breed on this plant under natural conditions. Delphinium is an unfavorable food plant of the short-winged and long-winged aster leafhoppers; some of the insects feeding on the plant died within 4 to 6 hours, and most of them within 24 .

Sugar-Beet Curly Top.-Ball (1906) associated the abundance of the beet leafhopper with curly top in the beet fields. Considerable controversy appears in the literature as to whether he was the first to prove that curly top was induced by this insect. He caged 14 beets in the field, introduced beet leafhoppers into 7 cages, and used 7 as controls (Ball, 1909). Cages 1 to 3 were failures; the insects escaped. Ball stated "Temperature and moisture could not be controlled and no curly top was produced in the remaining cages." In another experiment, 12 leafhoppers and their eggs stopped the growth of a beet in less than 2 weeks ; and they together with their progeny killed it in less than 2 weeks more. A footnote reports the occurrence of curly top in cages arranged by T. G. Titus in joint investigations with Ball. Shaw (1910) demonstrated that the beet leafhopper caused curly top of sugar beets in cages in the field. The leafhopper occurs in British Columbia (Davis, 1927), western United States (Severin, 1933), Lower California (Severin and Henderson, 1928), and western Mexico as far south as Guasave, Sinaloa (California Agricultural Experiment Station, 1928).

Fawcett (1927) reported a similar curly-top disease of sugar beets in Argentina-a different strain of the virus, transmitted by the leafhopper Agallian ensigera Oman. This leafhopper was first determined as Agallia sanguinolenta (Prov.) by McAtee in 1928 and later (during the same year) as A. sticticollis Stal by Osborn and Ball. A. sticticollis is the species referred to by Fawcett $(1925,1927)$ and by Severin and Henderson (1928) ; but Oman (1934), examining numerous specimens from Fawcett and Henderson, failed to find Stal's species in any of the material. There seems to be at present no reason to believe that $A$. sticticollis occurs in the sugar-beet-growing regions of the Argentine Republic. 
Pierce's Disease of Grapevine and Alfalfa Dwarf.---Hewitt, Frazier, and Houston (1942) reported that two undetermined species of leafhoppers in the genera Draeculacephala and Carneocephala transmitted the virus of Pierce's disease of grapevine. In a later paper Hewitt, Frazier, Jacobs, and Freitag (1942) named, as vectors of the virus, the green sharpshooter, D. minerva Ball; the redheaded sharpshooter, C. fulgida Nott.; and the blue-green sharpshooter, Neokolla circellata (Baker) $=[$ Cicadella circellata (Baker) $]$. Frazier (1945) lists the following 6 additional species of leafhoppers as vectors: Carneocephala triguttata Nott., Helochara delta Oman, Neokolla gothica (Sign.), N. confluens (Uhler), N. heiroglyphica (Sat.), and Cuerna occidentalis Oman \& Beamer. All are species of the subfamily Amblycephalinae $=($ Cicadellinae $)$, according to Medler (1942).

Alfalfa Witches'-Broom.-Menzies (1944) has presented evidence that the leafhopper Platymoides acutus Say is the vector of the virus of alfalfa witches'-broom. This disease occurs in Washington.

False Blossom of Cranberry.-Dobroscky $(1929,1931)$ demonstrated that the virus of false blossom of cranberries is transmitted by the blunt-nosed leafhopper, Euscelis striatulus Fall. The disease occurs wherever cranberries are grown in the United States.

Peach Yellows.-Kunkel (1933) proved that the vector of peach-yellows virus is the plum leafhopper, Macropsis trimaculata (Fitch). The dissemination of the virus in nature had defied the efforts of plant pathologists for fortyfive years. Peach yellows is limited in its distribution to the eastern United States.

Potato Yellow Dwarf.-Black (1937) has proved that virus of potato yellow dwarf is transmitted by the clover leafhopper, Acertatagallia sanguinolenta (Prov.) ; and his findings were confirmed by Walker and Larson (1938). In a later paper Black (1941) reported that $A$. sanguinolenta carried a strain of virus from New York and that Agallia constricta V. D. transmitted a strain of virus from New Jersey. According to him, "the results indicate that there exists a high degree of specificity, perhaps an absolute specificity, in the relationship between the two varieties of virus and the two related leafhoppers."

Clover Club-Leaf.-In a recent paper, Black (1944) reported that Agalliopsis novella (Say) collected near Washington, D. C., transmitted two viruses to crimson clover; but in nature the diseases are unknown.

Dwarf or Stunt Disease of Rice.-The relation of leafhoppers to the dwarf disease of rice was first experimentally proved by Hatsuzo Hashimota, a local grower of Shiga prefecture, in 1884, according to Ishikawa (1928) on the authority of Katsura (1936). Takata (1895-96) concluded that among several leafhoppers investigated, Deltocephalus dorsalis Motsch. was not the vector of the virus causing dwarf disease of rice; but in his further investigations in 1900 Takata reported that only the rice leafhopper, Nephotettix apicalis Motsch. var. cincticeps Uhl., was capable of transmitting the virus. According to Fukushi (1937), Japanese plant pathologists have generally regarded the rice leafhopper as the sole agent that transmits the virus. In his studies on the relation of several species of leafhoppers to the transmission of the virus, $D$. dorsalis proved to be another vector. Dwarf of rice has been a serious disease in Japan for many years. 
Agati, Sison, and Abolis (1941) demonstrated that the rice leafhopper, Nephotettix bipunctatus cincticeps, is also the vector of the virus of dwarf disease of rice in central Luzon.

Streak of Corn (Maize).-Storey $(1925 a, 1928)$ reported the transmission of the virus of corn by the maize leafhopper, Cicadulina mbila (China) $=($ Balclutha mbila Naude). Later he found that two other closely related species, C. zeal China and C. storeyi China, carry the virus (Storey, 1937). The most efficient vector is $C$. mbila. Evidently, 3 species of leafhoppers belonging to one genus transmit the virus. Streak of corn is a destructive disease in South Africa.

Mottle of Corn (Maize).--Storey (1937) discussed the transmission of the virus of mottle of corn by 3 species of leafhoppers-Cicadulina mbila Naude, C. zeal China, and C. storeyi China. He suggests that the mottle and streak viruses may be regarded as two strains of one virus. In his text and summary, however, he states: "The mottle virus is regarded as a new one, unrelated to that of streak disease." This is the first example of 2 viruses being transmitted by the same 3 species of leafhoppers. An insect already carrying one virus may also take up and transmit the other. The disease has been found in Tanganyika Territory.

Streak Disease of Sugar Cane.-Storey (1925b) reported that the virus of streak of sugar cane is spread only by the maize leafhopper, Cicadulina mbila. By feeding the leafhoppers on the tip of a single leaf of diseased sugar cane and then transferring them to the tip of a single leaf of healthy cane, he caused 5 to 19 plants to develop streak. The virus from corn caused only a transitory infection of sugar cane, from which the plant subsequently recovered. The virus from sugar cane produced in corn a permanent but mild form of streak disease. Storey and McClean (1930) concluded that the virus of corn streak and the virus of cane streak are not identical. Evidently, C. mbila transmits 3 viruses.

According to Storey (1926), attenuation of the virus of cane streak occurred in passage from sugar cane to corn by use of the maize leafhopper, Cicadulina mbila. The transfer of the virus to corn streak to cane caused only a few chlorotic stripes, and the foliage was healthy thereafter. The cane plants were therefore thought to have been infected by the virus from maize, but to have recovered from it.

Sugar-Cane Mosaic.-No leafhopper is known to transmit a mosaic virus up to the present time. Kunkel (1944) in a review of Bawden's (1943) book called attention to the fact that the virus of sugar-cane mosaic is disseminated by aphids, but is not known to be transmitted by any species of leafhopper. Brandes (1920), Ingram and Summers (1936), Ingram (1937), Ingram, Haley, and Charpentier (1939) reported that Draeculacephala portola Ball= [D. mollipes (Say) Abbott and Ingram (1942)], failed to transmit the virus of sugar-cane mosaic. The following species of aphids are vectors of the virus : corn aphid, Aphis maidis Fitch, reported by Brandes (1920), Kunkel (1922), and Chardon and Veve (1922); rusty plum aphid, Hysteroneura setariae (Thomas), reported by Ingram and Summers (1936), Ingram (1937), and Ingram, Haley, and Charpentier (1939); spring grain aphid, Toxoptera graminum Rond., reported by Ingram (1937), Ingram and Summers (1938), 
and Ingram, Haley, and Charpentier (1939) ; and Carolinaia cyperi Ainslie, Tate, and Vanderberg (1939).

Chlorotic Streak of Sugar Cane.-Abbott and Ingram (1942) offer proof that the leafhopper Draeculacephala portola is a vector of the virus of chlorotic streak of sugar cane. The disease occurs in the Gulf states.

Yellow Dwarf of Tobacco.-According to Hill (1941), the leafhopper Thamnotettix argentea (Evans) is the vector of the virus of tobacco yellow dwarf in Australia.

Wallaby Ear Disease of Corn (Maize).--Schindler (1942) concluded that the leafhopper Cicadula bimaculata Evans is responsible for the wallaby ear disease, which is probably caused by a virus. He reported transmission to corn in 2 cages containing $C$. bimaculata; and in 4 of 5 cages containing $C$. bimacu$l a t a$ and the corn leafhopper (fulgorid) Peregrinus maidis Ash. In 1 cage containing $P$. maidis, the disease failed to develop.

Big Bud of Tomato.- Hill $(1937,1943)$ reported that the virus of big bud of tomato and tobacco yellow dwarf was transmitted by the leafhopper Thamnotettix argentea (Evans). The list of additional economic plants experimentally infected by $T$. argentea includes eggplant, pepper, sugar beet, white and red clover, also ornamental flowering plants and weeds, a total of 23 species of plants of 13 families. Evidently this leafhopper transmits two viruses. Big bud of tomato occurs in all the Australian states.

Ryjkoff (1935) and Ryjkoff and Karatchevsky (1935) consider tomato woodiness, virescence of tobacco flowers, belladonna, and weeds in the Crimea and Ukraine to be identical with big bud of tomato. They suggest that the leafhopper Agallia sinuata is responsible for its spread in the field.

Little-leaf of Eggplant.-Thomas and Krishnaswami (1939) reported that 2 species of leafhoppers disseminate a virus to eggplants. The virus was transmitted from diseased eggplants to 19 of 59 healthy plants by Eutettix phycitis Dis.; to 1 of 9 healthy plants by Empoasca devastens Dis. The disease causes considerable damage to the crop in south India, resulting in dwarfed leaves and sterility. Hill (1943) considers little-leaf of eggplant to be either the same as big bud of tomato or a closely related disease.

\section{VIRUS TRANSMISSION EXPERIMENTS AND BIOLOGY OF TEXANANUS LATHROPI BAKER AND T. LATIPEX DELONG}

A species of Texananus was collected on July 31, 1934, in miscellaneous sweepings on weeds, grasses, and ornamental flowering plants in South Canyon Nursery, near Montara, San Mateo County. A population was reared on celery infected with the California aster-yellows virus, but during the winter the leafhoppers died. This species proved to be T. latipex DeLong, described by DeLong (1943). Five years later 22 adults were collected by N. W. Frazier, on drying pasture vegetation in a mountainous area at an elevation of 1,800 feet near Triniti, Sonoma County, on April 25, 1939. A large population was reared on diseased celery. Adults were sent to P. M. Oman, Division of Insect Identification, Bureau of Plant Quarantine, Washington, D. C. Oman ${ }^{4}$ found a mixed population containing T. lathropi Baker and a new species. Before

\footnotetext{
${ }^{4}$ P. M. Oman in a letter to the author, dated May 6, 1941.
} 
he could publish a description of the latter, he joined the United States Army. He sent the leafhoppers to R. H. Beamer, University of Kansas, Lawrence, Kansas, for determination. Beamer forwarded the specimens to DeLong, who described the new species as T. latipex. Etherized females of the two species were separated from a mixed population by means of a binocular microscope, and the investigations were resumed.

A study was undertaken with the two species of leafhoppers to determine the efficiency of the vectors in transmitting the virus by single males and females, each kept on a healthy celery plant until symptoms of the disease developed, or for 2 months if no symptoms appeared. Varying numbers of adults were kept for different periods on healthy celery and asters and upon successive asters. Attempts were made to determine the latent period of the virus and the retention of the virus in the adults. The ability of the two leafhopper species to transmit the viruses of curly top and Pierce's disease of grapevine was also investigated. Life histories of the two phlepsid species were studied.

\section{METHODS AND EQUIPMENT USED WITH THE TWO VECTORS}

Etherized adult males and females of both species were segregated under a binocular microscope. The cages used and the method of transferring leafhoppers in a dark chamber have already been described (Severin, 1930,1931). Repeated capturing of the leafhoppers results in a mortality and was therefore avoided in all experiments. During transfers of the adults to successive healthy celery plants, the clay pot on which the cage rested was jarred on the table in a dark chamber, and a breath of air was blown between the petioles to free the plant from leafhoppers.

\section{TRANSMISSION OF CALIFORNIA ASTER-YELLOWS VIRUS}

To Celery by Single Males and Females.-An experiment was conducted on the transmission of the virus by 150 males and 150 females of Texananus lathropi, each kept singly on a healthy celery plant. The males and females had completed the nymphal stages on diseased celery, requiring an average of 59.5 and 66.4 days, respectively, during January and February (table 10). Whenever an infected celery plant became unfavorable as food, the nymphs were transferred to a second diseased celery plant. A total of 300 adults were kept singly on healthy celery. The males infected 28 of 150 plants inoculated or 18.7 per cent and the females 24 of 150 plants or 16.0 per cent.

$\Lambda$ similar test was made with 100 males and 100 females of Texananus latipex, each kept singly on a healthy celery plant. The males and females completed the nymphal stages on diseased celery, requiring an average of 52.6 days and 56.3 days, respectively, during February and March (table 10). The males infected 18 of 100 plants inoculated and the females 32 of 100 plants.

To Celery Alternating with Asters in Daily and Weekly Inoculations.-The transmission of the virus to successive celery and asters by each species of leafhopper was compared. Lots of 40 recently molted males or females, which had completed the nymphal stages on diseased celery, were transferred daily for 42 to 46 days to healthy celery alternating with asters. In a similar experi- 
ment weekly inoculations were made alternately on celery and asters. Table 1 indicates the results.

As this table shows, when the males and females of Texananus lathropi were transferred daily to celery alternating with asters, the males infected 20.2 and the females 11.4 per cent of the celery, respectively. When transferred weekly to celery alternating with asters, the males infected 50.0 and the females 45.8 per cent of the celery. Under the same conditions, transmission by T. latipex was as follows : daily transfers to celery, males 25.0 per cent and females 22.5 ; weekly transfers to celery, males 44.4 per cent and females 58.3. Evidently

\section{TABLE 1}

Transmission of Virus to Celery Alternating with Asters in Daily and Weekly Inoculations, BY Adult Texananus lathropi and T. latipex

\begin{tabular}{|c|c|c|c|c|c|c|c|c|}
\hline \multirow{2}{*}{$\begin{array}{l}\text { Number } \\
\text { of lots }\end{array}$} & \multirow{2}{*}{$\begin{array}{l}\text { Species and number of } \\
\text { adults in each lot }\end{array}$} & \multicolumn{3}{|c|}{ Celery } & \multicolumn{3}{|c|}{ Asters } & \multirow{2}{*}{$\begin{array}{l}\text { Adults } \\
\text { alive } \\
\text { at end of } \\
6 \text { weeks }\end{array}$} \\
\hline & & $\begin{array}{l}\text { Plants } \\
\text { inoc- } \\
\text { ulated }\end{array}$ & $\begin{array}{c}\text { Plants } \\
\text { infected }\end{array}$ & $\begin{array}{l}\text { Per cent } \\
\text { infected }\end{array}$ & $\begin{array}{l}\text { Plants } \\
\text { inoc- } \\
\text { ulated }\end{array}$ & $\begin{array}{c}\text { Plants } \\
\text { infected }\end{array}$ & $\begin{array}{l}\text { Per cent } \\
\text { infected }\end{array}$ & \\
\hline
\end{tabular}

Daily inoculations

\begin{tabular}{l|l|l|l|l|l|r|r|r}
\hline 8 & T.lathropi, 40 males..... & 168 & 34 & 20.2 & 168 & 2 & 1.2 & $20-35$ \\
8 & T.lathropi, 40 females.... & 184 & 21 & 11.4 & 179 & 2 & 1.1 & $21-33$ \\
$\mathbf{5}$ & T.latipex, 40 males...... & 116 & 29 & 25.0 & 113 & 4 & 3.5 & $18-33$ \\
$\mathbf{6}$ & T.latipex, 40 females..... & 138 & 31 & 22.5 & 135 & 14 & 10.4 & $16-35$ \\
\hline
\end{tabular}

Weekly inoculations

\begin{tabular}{l|r|r|r|r|r|r|r|r}
\hline 8 & T.lathropi, 40 males..... & 24 & 12 & 50.0 & 24 & 0 & 0.0 & $18-38$ \\
8 & T.lathropi, 40 females.... & 24 & 11 & 45.8 & 24 & 0 & 0.0 & $26-37$ \\
6 & T.latipex, 40 males...... & 18 & 8 & 44.4 & 18 & 2 & 22.2 & $35-39$ \\
4 & T.latipex, 40 females..... & 12 & 7 & 58.3 & 12 & 0 & 0.0 & $18-21$ \\
\hline
\end{tabular}

the period of exposure of healthy celery to the leafhoppers is important in the virus transmission.

A total of 347 asters were inoculated by lots of 40 males or females of Texananus lathropi in daily transfers, and 4, or 1.2 per cent, were infected; but of 48 asters inoculated in weekly transfers, none showed any effect. In daily transfers, lots of 40 males or females of T. latipex inoculated 248 asters, infected 18 or 7.3 per cent in daily transfers. They infected 2 of 30 asters, or 6.7 per cent in weekly transfers.

To Asters Alternating with Celery in Daily and Weekly Inoculations.T'he retention of the virus by single males and females of the two species of leafhoppers, to be discussed later, indicates that many leafhoppers cause only 1 infection apiece during adult life. For this reason, lots of 40 males and 40 females were transferred daily and weekly during a period of 6 weeks to asters alternating with celery, instead of celery alternating with asters as in the previous experiment. The results appear in table 2 : lower percentages of infection were obtained in asters and celery in daily than in weekly transfers with both species of leafhoppers. 
To Successive Celery Alternating with Asters, by Varying Numbers of Adults Reared on Infected Celery.--A study was made of the transmission of the virus by single males and by lots of 5,10 , and 20 males of Texananus latipex reared on diseased celery and transferred to celery alternating with asters.

TABLE 2

Transmission of Virus to Asters Alternating with Celery in Daily and Weekly InOCUlations, BY AdULt Texananus lathropi AND T. latipex

\begin{tabular}{|c|c|c|c|c|c|c|c|c|}
\hline \multirow{2}{*}{$\begin{array}{c}\text { Number } \\
\text { of lots }\end{array}$} & \multirow{2}{*}{$\begin{array}{l}\text { Species and number of } \\
\text { adults in each lot }\end{array}$} & \multicolumn{3}{|c|}{ Asters } & \multicolumn{3}{|c|}{ Celery } & \multirow{2}{*}{$\begin{array}{l}\text { Adults } \\
\text { alive } \\
\text { at end of } \\
6 \text { weeks }\end{array}$} \\
\hline & & $\begin{array}{l}\text { Plants } \\
\text { inoc- } \\
\text { ulated }\end{array}$ & $\begin{array}{l}\text { Plants } \\
\text { infected }\end{array}$ & $\begin{array}{l}\text { Per cent } \\
\text { infected }\end{array}$ & $\begin{array}{l}\text { Plants } \\
\text { inoc- } \\
\text { ulated }\end{array}$ & $\begin{array}{c}\text { Plants } \\
\text { inferted }\end{array}$ & $\begin{array}{l}\text { Per cent } \\
\text { infected }\end{array}$ & \\
\hline \multicolumn{9}{|c|}{ Daily inoculations } \\
\hline 4 & T. lathropi, 40 males..... & 84 & 9 & 10.7 & 84 & 28 & 33.3 & $20-23$ \\
\hline 5 & T. lathropi, 40 females. & 105 & 5 & 4.8 & 105 & 29 & 27.6 & $21-30$ \\
\hline 12 & T. latipex, 40 males... & 252 & 16 & 6.3 & 252 & 69 & 27.4 & $21-32$ \\
\hline \multicolumn{9}{|c|}{ Weekly inoculations } \\
\hline 8 & T. lathropi, 40 males. & 24 & 3 & 12.5 & 24 & 14 & 58.3 & $25-40$ \\
\hline 9 & T. lathropi, 40 females. & 24 & 2 & 8.3 & 24 & 7 & 29.2 & $25-36$ \\
\hline 11 & T. latipex, 40 males. & 27 & 4 & 14.8 & 27 & 16 & 59.3 & $20-36$ \\
\hline 8 & T. latipex, 40 females. & 24 & 8 & 33.3 & 24 & 12 & 50.0 & $24-35$ \\
\hline
\end{tabular}

TABLE 3

Transmission of Virus to Successive Celery Alternating with Asters, by Varying Numbers of A dult Texananus latipex ReARed on INFeCted Celery

\begin{tabular}{|c|c|c|c|c|c|c|c|}
\hline $\begin{array}{l}\text { Number of } \\
\text { of lots }\end{array}$ & $\begin{array}{c}\text { Number of males } \\
\text { in each lot }\end{array}$ & $\begin{array}{c}\text { Plants } \\
\text { inoculated }\end{array}$ & $\begin{array}{l}\text { Plants } \\
\text { infected }\end{array}$ & $\begin{array}{l}\text { Per cent } \\
\text { infected }\end{array}$ & $\begin{array}{c}\text { Plants } \\
\text { inoculated }\end{array}$ & $\begin{array}{c}\text { Plants } \\
\text { infected }\end{array}$ & $\begin{array}{l}\text { Per cent } \\
\text { infected }\end{array}$ \\
\hline & & \multicolumn{3}{|c|}{ First set of celery } & \multicolumn{3}{|c|}{ First set of asters } \\
\hline $\begin{array}{r}100 \\
50 \\
50 \\
50\end{array}$ & $\begin{array}{r}1 \\
5 \\
10 \\
20\end{array}$ & $\begin{array}{r}100 \\
50 \\
50 \\
50\end{array}$ & $\begin{array}{l}11 \\
12 \\
37 \\
40\end{array}$ & $\begin{array}{l}11.0 \\
24.0 \\
74.0 \\
80.0\end{array}$ & $\begin{array}{r}100 \\
50 \\
50 \\
50\end{array}$ & $\begin{array}{r}1 \\
2 \\
18 \\
12\end{array}$ & $\begin{array}{r}1.0 \\
4.0 \\
36.0 \\
12.0\end{array}$ \\
\hline 50 & & \multicolumn{3}{|c|}{ Second set of celery } & \multicolumn{3}{|c|}{ Second set of asters } \\
\hline 100 & 1 & .. & . & & .. & .. & $\ldots$ \\
\hline 50 & 5 & 50 & 4 & 8.0 & 50 & 0 & 0.0 \\
\hline 50 & 10 & 50 & 17 & 34.0 & 50 & 5 & 10.0 \\
\hline 50 & 20 & 50 & 11 & 22.0 & 50 & 4 & 8.0 \\
\hline
\end{tabular}

Each of the 100 males was kept on a healthy celery plant for 4 weeks and then was transferred to a healthy aster and kept there during adult life. Lots of 5 , 10 , and 20 males were changed weekly during a period of 4 weeks to successive celery plants alternating with asters. Table 3 shows the results.

One hundred males tested singly on celery and then on asters infected 11 celery plants and only 1 aster. Fifty lots of 5 males caused 24.0 per cent infec- 
tions of celery; 50 lots of 10 males, 74 per cent; and 50 lots of 20 males, 80 per cent. Again the period of exposure of healthy celery to leafhoppers influenced virus transmission.

The percentages of infections with the second set of celery, the first and second sets of asters, show no progressive increase with lots of 5, 10, and 20 males; but lower percentages were obtained with lots of 5 than with lots of 10 and 20 males.

To Successive Asters Alternating with Celery, by Varying Numbers of Adults Reared on Infected Asters.-In the previous experiment the percentages of infection showed no progressive increase with varying numbers of

TABLE 4

Transmission of Virus to Successive Asters Alternating with Celert, by Varying NuMbers OF AdULT Texananus latipex REAREd ON INFECTED ASTERS

\begin{tabular}{|c|c|c|c|c|c|c|c|}
\hline $\begin{array}{c}\text { Number } \\
\text { of lots }\end{array}$ & $\begin{array}{c}\text { Number of males } \\
\text { in each lot }\end{array}$ & $\begin{array}{c}\text { Plants } \\
\text { inoculated }\end{array}$ & $\begin{array}{c}\text { Plants } \\
\text { infected }\end{array}$ & $\begin{array}{l}\text { Per cent } \\
\text { infected }\end{array}$ & $\begin{array}{c}\text { Plants } \\
\text { inoculated }\end{array}$ & $\begin{array}{c}\text { Plants } \\
\text { infected }\end{array}$ & $\begin{array}{l}\text { Per cent } \\
\text { infected }\end{array}$ \\
\hline & & \multicolumn{3}{|c|}{ First set of asters } & \multicolumn{3}{|c|}{ First set of celery } \\
\hline 100 & 1 & 100 & 4 & 4.0 & 100 & 10 & 10.0 \\
\hline 100 & 5 & 100 & 4 & 4.0 & 100 & 5 & 5.0 \\
\hline 50 & 10 & 50 & 2 & 4.0 & 50 & 8 & 16.0 \\
\hline 50 & 20 & 50 & 8 & 16.0 & 50 & 20 & 40.0 \\
\hline \multirow[t]{2}{*}{6} & 40 & 6 & 1 & 16.7 & 6 & 5 & 83.5 \\
\hline & & \multicolumn{3}{|c|}{ Second set of asters } & \multicolumn{3}{|c|}{ Second set of celery } \\
\hline 100 & 1 & . & .. & $\ldots$ & $\ldots$ & .. & $\ldots$ \\
\hline .100 & 5 & 50 & 0 & 0.0 & 50 & 3 & 6.0 \\
\hline 50 & 10 & 50 & 2 & 4.0 & 50 & 7 & 14.0 \\
\hline 50 & 20 & 50 & 4 & 8.0 & 50 & 8 & 16.0 \\
\hline 6 & 40 & 6 & 0 & 0.0 & 6 & 4 & 66.7 \\
\hline
\end{tabular}

leafhoppers reared on infected celery; hence another experiment was conducted with males of Texananus latipex reared on diseased asters. Table 4 gives the results.

One hundred males each tested singly on healthy celery for 4 weeks, infected 10 celery plants, as compared with 11 plants in the previous experiment. In the first and second sets of celery there was a progressive increase in the percentages of infections obtained with lots of $5,10,20$, and 40 males transferred weekly. Again there was no progressive increase in the percentages of infections with lots of varying numbers of adults in the first and second sets of asters. The number of leafhoppers, however, plays an important role in the transmission of virus to celery.

To Successive Asters by Adults Reared on Infected Asters.-In the experiment on the transmission of the virus to celery alternating with asters, no asters became infected by lots of 40 males or females of Texananus lathropi, or by females of $T$. latipex in weekly inoculations (table 2 ). In the experiment on transmission to asters alternating with celery, the percentages of infections by both species of leafhoppers in weekly inoculations varied considerably. For this reason another experiment was inaugurated in which the period 
of exposure on each successive aster was increased to 3 weeks with lots of 40 males or females of T. latipex reared on diseased asters. The results are indicated in table 5 .

A total of 56 asters were inoculated by 10 lots of 40 males each, and 24 asters or 42.9 per cent were infected; and 27 of 55 asters or 49.1 per cent were infected by lots of 40 females (table 5). With both males and females, the highest percentages of infections were obtained with the first set of asters. As the results show, the period of exposure of healthy asters to infective adults affects the percentages of infections obtained.

\section{TABLE 5}

Transmission of Virus to Successive Sets of Asters Inoculated for Three Weeks, By Adult Texananus latipex ReAred on INFECTEd Asters

\begin{tabular}{|c|c|c|c|c|c|c|c|}
\hline $\begin{array}{l}\text { Number } \\
\text { of lots }\end{array}$ & $\begin{array}{l}\text { Number of adults } \\
\text { in each lot* }\end{array}$ & $\begin{array}{c}\text { Plants } \\
\text { inoculated }\end{array}$ & $\begin{array}{l}\text { Plants } \\
\text { infected }\end{array}$ & $\begin{array}{l}\text { Per cent } \\
\text { infected }\end{array}$ & $\begin{array}{c}\text { Plants } \\
\text { inoculated }\end{array}$ & $\begin{array}{l}\text { Plants } \\
\text { infected }\end{array}$ & $\begin{array}{l}\text { Per cent } \\
\text { infected }\end{array}$ \\
\hline \multirow{3}{*}{$\begin{array}{l}10 \\
10\end{array}$} & \multirow{3}{*}{$\begin{array}{l}40 \text { males. . . . . . . . . . . . . . } \\
40 \text { fernales . . }\end{array}$} & \multicolumn{3}{|c|}{ First set of asters } & \multicolumn{3}{|c|}{ Second set of asters } \\
\hline & & $\begin{array}{l}10 \\
10\end{array}$ & $\begin{array}{r}10 \\
8\end{array}$ & $\begin{array}{r}100.0 \\
80.0\end{array}$ & $\begin{array}{l}10 \\
10\end{array}$ & $\begin{array}{l}4 \\
6\end{array}$ & $\begin{array}{l}40.0 \\
60.0\end{array}$ \\
\hline & & \multicolumn{3}{|c|}{ Third set of asters } & \multicolumn{3}{|c|}{ Fourth set of asters } \\
\hline \multirow[t]{2}{*}{$\begin{array}{l}10 \\
10\end{array}$} & \multirow[t]{2}{*}{$\begin{array}{l}40 \text { males............... } \\
40 \text { females. . . . . . . }\end{array}$} & $\begin{array}{l}10 \\
10\end{array}$ & $\begin{array}{l}5 \\
4\end{array}$ & $\begin{array}{l}50.0 \\
40.0\end{array}$ & $\begin{array}{l}10 \\
10\end{array}$ & $\begin{array}{l}3 \\
4\end{array}$ & $\begin{array}{l}30.0 \\
40.0\end{array}$ \\
\hline & & & th set of as & & & h set of a & \\
\hline \multirow[t]{2}{*}{$\begin{array}{l}10 \\
10\end{array}$} & $\begin{array}{l}40 \text { males } . \ldots \ldots \ldots \ldots \ldots \\
40 \text { females } . \ldots \ldots \ldots \ldots\end{array}$ & $\begin{array}{l}9 \\
8\end{array}$ & $\begin{array}{l}0 \\
1\end{array}$ & $\begin{array}{r}0.0 \\
12.5\end{array}$ & $\begin{array}{l}7 \\
7\end{array}$ & $\begin{array}{l}2 \\
4\end{array}$ & $\begin{array}{l}28.6 \\
57.1\end{array}$ \\
\hline & & \multicolumn{3}{|c|}{ Total of all sets } & & & \\
\hline $\begin{array}{l}10 \\
10\end{array}$ & $\begin{array}{l}40 \text { males............... } \\
40 \text { females } . \ldots \ldots \ldots \ldots \ldots\end{array}$ & $\begin{array}{l}56 \\
55\end{array}$ & $\begin{array}{l}24 \\
27\end{array}$ & $\begin{array}{l}42.9 \\
49.1\end{array}$ & & & \\
\hline
\end{tabular}

* Adults alive at the end of 12 to 18 weeks: males, $11-28$; females, 15-35.

\section{LATENT PERIOD OF VIRUS IN ADULTS}

The literature on the so-called virus-incubation period in leafhoppers may be briefly reviewed. Smith and Boncquet (1915) were first to use the term "incubation period of the inciting agent of curly leaf" in connection with the beet leafhopper. Severin (1921) mentioned the "incubation period of the causative agent of curly leaf" in the same insect and later (1931) spoke of the "virus-incubation period." As pointed out by Bawden (1943), the term "incubation period" implies a fixed time during which the virus develops or multiplies. Storey (1939) wrote of "a delay in the development of infective ability," termed by other workers the "latent," "waiting," or "incubation period," and he coupled it with the retention of the virus by the vectors. Leach (1940) employs the term "latent period" in his textbook.

The latent period of the virus in the two species of leafhoppers was deter- 
mined by using lots of 80 previously noninfective males or females, which were kept on diseased celery for 1 day. Daily transfers were made to successive healthy celery during a period of 41 days. The mortality of the adults by the end of 42 days was recorded. The results appear in table 6 .

The minimum latent period of the virus in Texananus lathropi, using 80 males or females, was 7 and 8 days, respectively; in T. latipex, with 1 lot of 80 males, it was 8 days (table 6 ). The maximum latent period in T. lathropi was 33 days with 80 females; in T. latipex, 37 days with 80 males. Four lots of 80 adults of $T$. lathropi and 3 lots of $T$. latipex failed to transmit the virus.

TABLE 6

Latent Period of Virus in Adults of Two Species of Phlepsids, on Diseased Celery

\begin{tabular}{c|c|c|c|c|c}
\hline \hline $\begin{array}{c}\text { Days on } \\
\text { infected } \\
\text { celery }\end{array}$ & $\begin{array}{c}\text { Successive } \\
\text { plants } \\
\text { inoculated }\end{array}$ & $\begin{array}{c}\text { Plants } \\
\text { infected }\end{array}$ & $\begin{array}{c}\text { Per cent } \\
\text { infected }\end{array}$ & $\begin{array}{c}\text { Days after transfer on which successive } \\
\text { infections occurred, including } \\
\text { initial day on infected celery }\end{array}$ & $\begin{array}{c}\text { Adults alive } \\
\text { at end of } \\
\text { 42 days }\end{array}$ \\
\hline
\end{tabular}

Two lots of 80 males each, Texananus lathropi

\begin{tabular}{r|r|r|r|r|r|r}
\hline 1 & 41 & 15 & 36.6 & $7,10,13,14,16,17,20,21,22,23,25,28,30,31,42$. & 38 \\
1 & 41 & 6 & 14.6 & $9,13,19,20,30,35 \ldots \ldots \ldots \ldots \ldots \ldots \ldots \ldots \ldots$ & 37 \\
\hline \\
\hline \\
\hline 1
\end{tabular}

Two lots of 80 males each, Texananus latipex

\begin{tabular}{|c|c|c|c|c|c|}
\hline 1 & 41 & 17 & 41.5 & 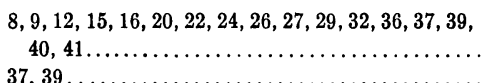 & $\begin{array}{l}41 \\
32\end{array}$ \\
\hline & & & & & \\
\hline
\end{tabular}

\section{RETENTION OF VIRUS}

By Varying Numbers of Adults.-To determine whether a longer period of exposure on diseased celery to varying numbers of adults is a factor in transmission of the virus, lots of 40,20, and 10 males or females were kept on diseased celery for 8 days, and then each lot was transferred daily to healthy celery during 34 days (table 7 ).

As table 7 shows, two lots of 40 males and 1 lot of 20 males of Texananus lathropi produced 3 infections and 1 lot of 40 males caused 2 infections. Single infections occurred with 13 lots of 40,20, and 10 adults of $T$. lathropi and 4 lots of 40 males of $T$. latipex. Evidently the number of leafhoppers kept on diseased celery for 8 days, and then transferred daily to healthy celery during a period of 34 days, determines the number of infections obtained. Seven lots of 40, 9 lots of 20 , and 11 lots of 10 adults of T. lathropi and 6 lots of 40 and 4 lots of 20 males of $T$. latipex failed to cause infection.

Since 7 lots of 80 adults of Texananus lathropi produced 2 to 15 infections 
TABLE 7

RETENTION OF VIRUS BY VARYing NuMBERS OF AdUL'T Texananus lathropi and T. latipex

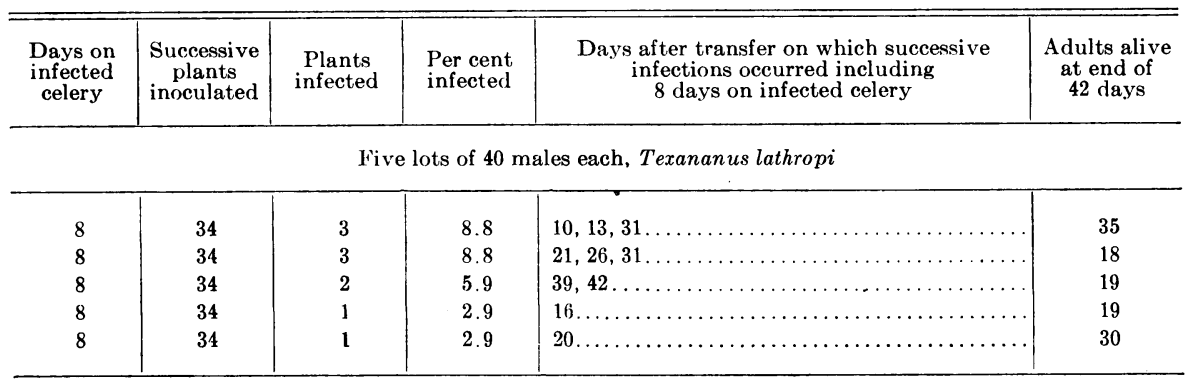

Four lots of 40 females each, Texananus lathropi

\begin{tabular}{|c|c|c|c|c|c|}
\hline 8 & 34 & 1 & 2.9 & $15 \ldots \ldots \ldots \ldots$ & 14 \\
\hline 8 & 34 & 1 & 2.9 & $20 \ldots$ & 28 \\
\hline 8 & 34 & 1 & 2.9 & 30. & 33 \\
\hline
\end{tabular}

Three lots of 20 males each, Texananus lathropi

\begin{tabular}{|c|c|c|c|c|c|}
\hline 8 & 34 & 3 & 8.8 & $36,41,42 \ldots$ & 13 \\
\hline 8 & 34 & 1 & 2.9 & $38 \ldots \ldots \ldots \ldots \ldots \ldots \ldots \ldots \ldots \ldots \ldots \ldots \ldots \ldots$ & 16 \\
\hline 8 & 34 & 1 & 2.9 & 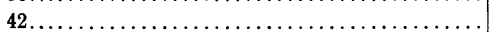 & 10 \\
\hline
\end{tabular}

Two lots of 20 females each, Texananus lathropi

\begin{tabular}{|c|c|c|c|c|c|}
\hline 8 & 34 & 1 & 2.9 & $35 \ldots$ & 17 \\
\hline 8 & 34 & 1 & 2.9 & $41 \ldots \ldots \ldots \ldots \ldots \ldots \ldots \ldots \ldots \ldots$ & 15 \\
\hline
\end{tabular}

Two lots of 10 males each, Texananus lathropi

\begin{tabular}{|c|c|c|c|c|c|}
\hline \multicolumn{6}{|c|}{ One lot of 10 females, Texananus lathropi } \\
\hline \multicolumn{6}{|c|}{ Three lots of 40 males each, Texananus latipex } \\
\hline $\begin{array}{l}8 \\
8 \\
8\end{array}$ & $\begin{array}{l}34 \\
34 \\
34\end{array}$ & $\begin{array}{l}1 \\
1 \\
1\end{array}$ & $\begin{array}{l}2.9 \\
2.9 \\
2.9\end{array}$ & 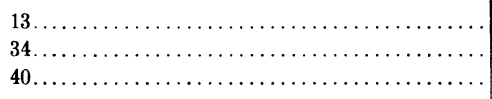 & $\begin{array}{l}29 \\
20 \\
26\end{array}$ \\
\hline \multicolumn{6}{|c|}{ One lot of 20 males, Texananus latipex } \\
\hline 8 & 34 & 1 & 2.9 & $17 \ldots$ & 16 \\
\hline
\end{tabular}


(table 6) or an average of 5.3, in determining the latent period of the virus, it seemed desirable to increase the time spent on diseased celery. Two lots of 80 female $T$. lathropi, after completing the nymphal stages on infected celery, an average of 66.4 days (table 10), were provided with healthy celery for 41 days. Each of the 2 lots caused 23 infections, or 56.1 per cent. Again it is evident that the amount of virus obtained by the nymphs in a long period on diseased celery, and the number of adults used, influences the number of infections produced.

By Single Adults.-The retention of the virus was determined by single males and females of both species of leafhoppers, all of which completed the nymphal stages on infected celery. Each leafhopper was confined in a cage enclosing a healthy celery plant until symptoms developed and then was transferred daily to successive healthy celery plants during adult life. The results are indicated in table 8.

The virus was retained 5 to 77 days (males) or 62 days (females) by $T e x$ ananus lathropi; 22 to 39 days (males) and 1 to 42 days (females) by $T$. latipex. Two adults of T. lathropi and 10 of T. latipex caused only 1 infection each. The period on the first plant is not included in the retention of the virus, since the adults were able to acquire the virus again.

\section{ATTEMPTS TO TRANSMIT VIRUSES OF CURLY TOP AND PIERCE'S DISEASE OF GRAPEVINE}

Because of the interest in two other prevalent viruses, attempts were made to transmit these by means of the two species of leafhoppers.

Fifty noninfective female Texananus lathropi and 50 noninfective male T. latipex were kept on curly-top beets for 2 days after which each lot was transferred to 10 successive healthy sugar beets. All beets remained healthy. At the end of 12 days, 43 females of $T$. lathropi and 40 males of T. latipex were alive.

Texananus lathropi failed to transmit the virus of Pierce's disease of grapevine to 10 healthy grapevines and 10 plants of common or Chilean alfalfa, Medicago sativa L.; and from alfalfa dwarf to 10 healthy grapevines and 10 alfalfa plants. T. latipex also failed to transmit that same virus to 5 healthy grapevines and 5 alfalfa plants and from alfalfa dwarf to 10 healthy grapevines and 5 alfalfa plants.

\section{BIOLOGY OF TEXANANUS LATHROPI AND T. LATIPEX}

DeLong and Severin (1945) have described the characters of the male and female Texananus lathropi and T. latipex. These closely related species can be readily distinguished by the U-shaped excavation (plate $1, A$ ) which extends halfway through the last ventral segment of the female T. lathropi and by the $\mathrm{V}$-shaped indentation (plate $1, B$ ) of the posterior margin of the last sternite of $T$. latipex.

According to Osborn and Lathrop (1923), very few species of Phlepsius have been studied for life history; there is an opportunity for careful work in determining detail of habits, life history, and ecology.

Oviposition.-The eggs of Texananus lathropi are deposited in two rows in the petioles of celery (plate 1, C) or in the stems of aster plants. One egg of 


\section{TABLE 8}

Retention of Virus by Single Adults of Two Species of Phlepsids with Celery as the Host Plant

\begin{tabular}{c|c|c|c|c|c}
\hline $\begin{array}{c}\text { Days on } \\
\text { frst plant } \\
\text { before } \\
\text { symptoms } \\
\text { developed }\end{array}$ & $\begin{array}{c}\text { Plants } \\
\text { inoculated } \\
\text { after } \\
\text { first } \\
\text { infection }\end{array}$ & $\begin{array}{c}\text { Plants } \\
\text { infected } \\
\text { after } \\
\text { first } \\
\text { infection }\end{array}$ & $\begin{array}{c}\text { Per cent } \\
\text { infected } \\
\text { after } \\
\text { first } \\
\text { infection }\end{array}$ & $\begin{array}{c}\text { Days after first infection } \\
\text { on which successive } \\
\text { infections occurred }\end{array}$ & $\begin{array}{c}\text { Longevity } \\
\text { of adults, } \\
\text { days }\end{array}$ \\
\hline
\end{tabular}

Six lots of single males, Texananus lathropi

\begin{tabular}{|c|c|c|c|c|c|}
\hline 28 & 77 & 12 & 15.6 & $37,39,41,44,47,53,55,57,58,58,68,72,77 \ldots \ldots \ldots$ & 105 \\
\hline 29 & 24 & 6 & 25.0 & $4,5,6,15,17,21 \ldots \ldots \ldots \ldots \ldots \ldots \ldots \ldots \ldots \ldots \ldots$ & 53 \\
\hline 28 & 11 & 2 & 1.8 & 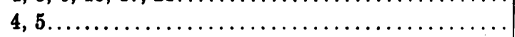 & 39 \\
\hline 29 & 80 & 1 & 1.2 & 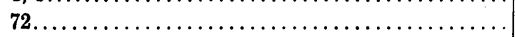 & 109 \\
\hline 29 & 86 & 1 & 1.2 & 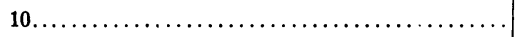 & 115 \\
\hline 28 & 79 & 0 & 0.0 & 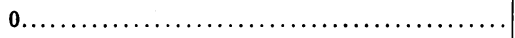 & 107 \\
\hline
\end{tabular}

Two lots of single females, Texananus lathropi

\begin{tabular}{r|r|r|r|r|r|r}
\hline 26 & 56 & 1 & 1.8 & $62 \ldots \ldots \ldots \ldots \ldots \ldots \ldots \ldots \ldots \ldots \ldots \ldots \ldots \ldots \ldots \ldots \ldots \ldots \ldots \ldots \ldots \ldots \ldots \ldots \ldots \ldots \ldots \ldots \ldots \ldots \ldots$ & 82 \\
34 & 95 & 0 & 0.0 & $0 \ldots \ldots \ldots \ldots \ldots \ldots \ldots \ldots$ & 129 \\
\hline
\end{tabular}

Eleven lots of single males, Texananus latipex

\begin{tabular}{|c|c|c|c|c|c|}
\hline 30 & 98 & 5 & 5.1 & $26,27,28,36,39 \ldots \ldots \ldots \ldots \ldots \ldots \ldots \ldots \ldots \ldots \ldots$ & 128 \\
\hline 24 & 34 & 4 & 11.8 & $14,32,33,34 \ldots \ldots \ldots \ldots \ldots \ldots \ldots \ldots \ldots \ldots \ldots \ldots$. & 58 \\
\hline 28 & 28 & 1 & 3.6 & 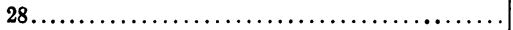 & 56 \\
\hline 23 & 76 & 1 & 1.3 & 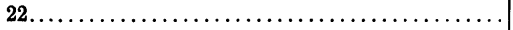 & 99 \\
\hline 30 & 80 & 0 & 0.0 & 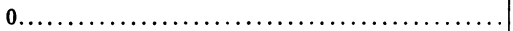 & 110 \\
\hline 30 & 59 & 0 & 0.0 & 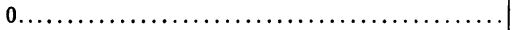 & 89 \\
\hline 28 & 41 & 0 & 0.0 & 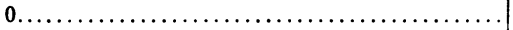 & 69 \\
\hline 30 & 19 & 0 & 0.0 & 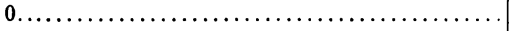 & 49 \\
\hline 26 & 15 & 0 & 0.0 & 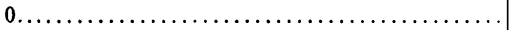 & 41 \\
\hline
\end{tabular}

Nine lots of single females, Texananus latipex

\begin{tabular}{|c|c|c|c|c|c|}
\hline 25 & 44 & 8 & 18.2 & $8,10,14,23,25,29,33,37 \ldots \ldots \ldots \ldots \ldots \ldots \ldots \ldots$ & 69 \\
\hline 32 & 103 & 7 & 9.6 & $2,5,19,20,30,40,42 \ldots \ldots \ldots \ldots \ldots \ldots \ldots \ldots \ldots \ldots$ & 135 \\
\hline 36 & 29 & 1 & 3.4 & 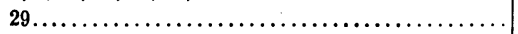 & 65 \\
\hline 33 & 28 & 1 & 3.6 & $14, \ldots \ldots \ldots \ldots \ldots \ldots \ldots \ldots, \ldots \ldots \ldots \ldots \ldots$, & 61 \\
\hline 45 & 2 & 1 & 50.0 & 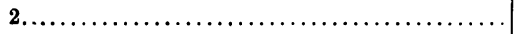 & 47 \\
\hline 21 & 1 & 1 & 100.0 & 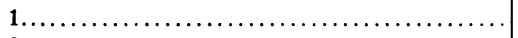 & 22 \\
\hline 42 & 51 & 0 & 0.0 & 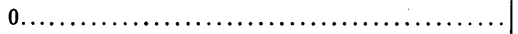 & 93 \\
\hline
\end{tabular}

one row is deposited between two eggs of the opposite row (plate $1, D$ ). The petiole sometimes cracks when long rows of eggs are deposited. After inserting the egg in the petiole, the female secrets a liquid (which becomes white when dry) in the form of a papilla over each egg puncture. Sometimes the papilla terminates in a hairlike structure. The papillae covering two eggs in opposite rows are arranged in $\mathrm{V}$ shape. In hatching, the nymph often pushes off the papilla. After all the nymphs have emerged from two rows of eggs, the zigzag 
arrangement of the openings of the egg punctures can readily be seen with a binocular microscope. The papilla is a secretion from the accessory glands and probably protects the eggs from parasites.

The eggs of Texananus latipex are deposited singly or in one short row. A quantity of accessory gland secretion covers the egg puncture and may be flattened against the petiole; or the papilla may be upright or vertical, terminating in a hair.

\section{TABLE 9}

Duration of Egg Periods and Daily Emergence of Nymphs of Two SPECIES OF PHLEPSIDS

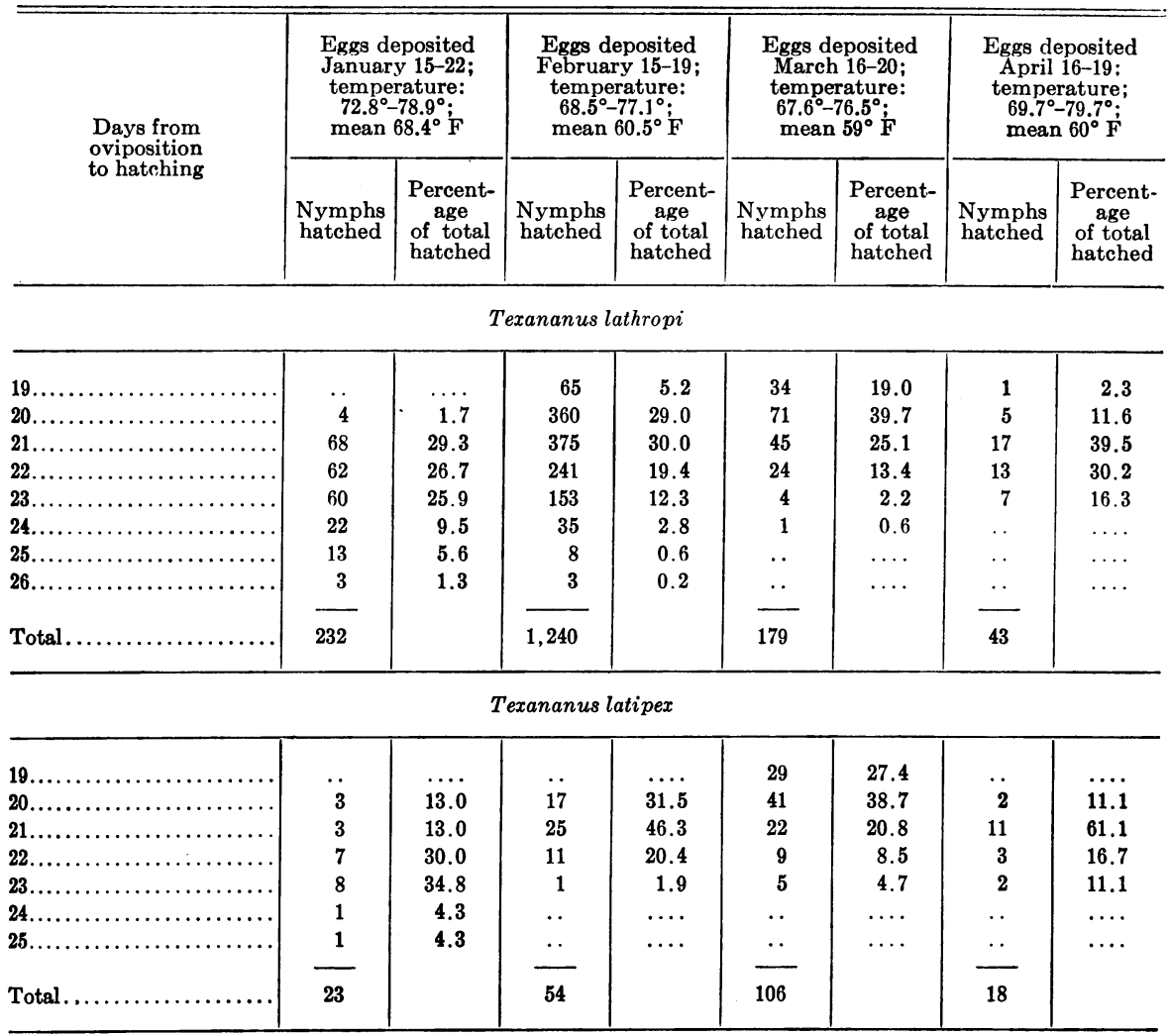

$E g g$.-The average length of eggs deposited by the two species of leafhoppers is $1.05 \mathrm{~mm}$; the average width $0.28 \mathrm{~mm}$. The eggs are translucent when first deposited. They are elongated and are narrower at one end than at the other. Near the hatching period, the compound eyes of the embryo become visible.

Egg Periods.-The egg periods of each species of leafhopper were determined from eggs deposited during 4 months from January to April, inclusive. Females of each species were confined in cages enclosing potted celery plants and were transferred daily to successive plants during a period of 3 to 7 days. The plants in which the eggs were deposited were covered with cages and ob- 
TABLE 10

Duration of Periods between Molts of Two Species of Phlepsids

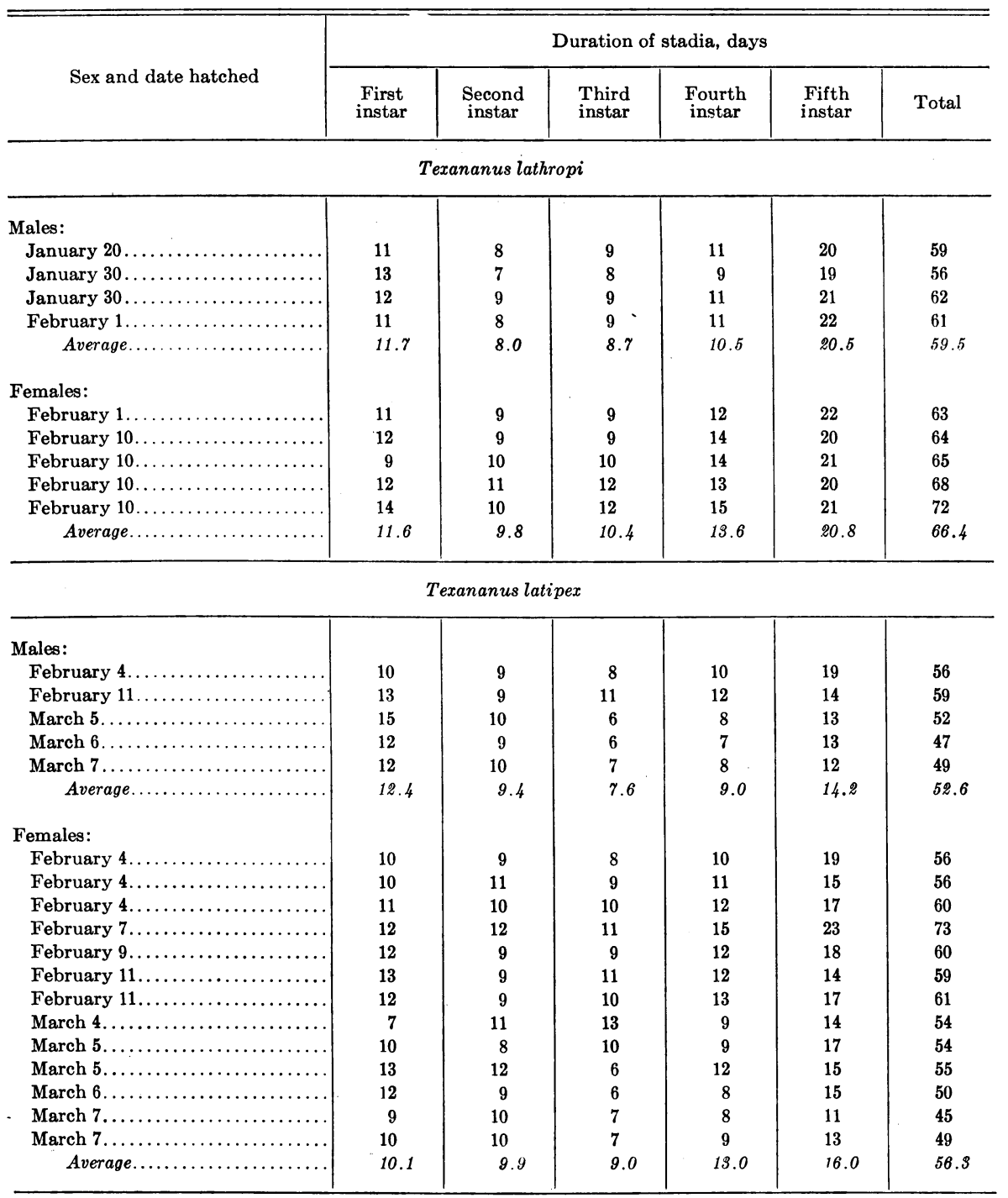

served daily for the hatching of nymphs. Eggs deposited during one day usually hatched over a period of several days. In an effort to measure the egg periods more accurately, a daily count of the nymphs hatched in each cage was taken, and the results of each monthly test were summed up and tabulated. The egg periods, with the number and percentage of nymphs that hatched, are indicated in table 9.

As this table shows, the egg periods of Texananus lathropi were longer with 
eggs deposited in January and February than with those laid in March and April. In T. latipex the periods were longer with eggs deposited in January than with those dating from February, March, and April. T. lathropi produced more eggs than T. latipex, though approximately equal numbers of females were used. Conceivably, a higher percentage of the T. lathropi may have been at the egg-laying stage.

Period between Molts. - The interval or period between molts (stages or stadia) and the total duration of the nymphal stages of both species of leaf-

TABLE 11

Average Measurements in Milimmeters of 'T'wo Species of Phlepsids AFTER EACH MOLT

\begin{tabular}{|c|c|c|c|c|c|c|}
\hline \multirow{2}{*}{ Nymphs and adults } & \multicolumn{2}{|c|}{$\begin{array}{l}\text { Diameter, head across } \\
\text { compound eyes }\end{array}$} & \multicolumn{2}{|c|}{$\begin{array}{l}\text { Length, head, thorax, } \\
\text { and abdomen }\end{array}$} & \multicolumn{2}{|c|}{$\begin{array}{l}\text { Length, head to end } \\
\text { of wings }\end{array}$} \\
\hline & Range & Mean & Range & Mean & Range & Mean \\
\hline \multicolumn{7}{|c|}{ Texananus lathropi } \\
\hline First instar. . & $0.40-0.43$ & 0.41 & $1.15-1.32$ & 1.24 & $\ldots \ldots$ & $\ldots$ \\
\hline Second instar... & $0.53-0.57$ & 0.55 & $1.62-2.16$ & 1.81 & $\ldots$ & $\ldots$ \\
\hline Third instar... & $0.73-0.76$ & 0.75 & $2.43-2.80$ & 2.60 & $\ldots \ldots$ & $\ldots$ \\
\hline Fourth instar.. & $0.94-1.03$ & 0.99 & $2.97-3.40$ & 3.16 & $\ldots \ldots$ & $\ldots$ \\
\hline Fifth instar........... & $1.27-1.36$ & 1.31 & $3.73-4.34$ & 4.03 & $\begin{array}{ll}\cdots & \cdots \\
\cdots & \cdots\end{array}$ & $\cdots$ \\
\hline Adult male...... & $1.39-1.44$ & 1.42 & $4.43-5.41$ & 5.02 & $4.59-5.20$ & 4.97 \\
\hline Adult female... & $1.46-1.55$ & 1.51 & $4.94-5.99$ & 5.43 & $5.08-5.48$ & 5.26 \\
\hline
\end{tabular}

Texananus latipex

\begin{tabular}{|c|c|c|c|c|c|c|}
\hline First instar. & $0.39-0.40$ & 0.40 & $1.15-1.38$ & 1.25 & $\ldots \ldots$ & $\ldots$ \\
\hline Second instar....... & $0.53-0.55$ & 0.54 & $1.59-1.89$ & 1.73 & $\ldots \ldots$ & $\ldots$ \\
\hline Third instar. & $0.66-0.71$ & 0.69 & $1.89-2.48$ & 2.21 & $\ldots \ldots$ & $\ldots$ \\
\hline Fourth instar....... & $0.89-0.96$ & 0.92 & $2.67-3.32$ & 2.84 & . & $\ldots$ \\
\hline Fifth instar......... & $1.17-1.31$ & 1.24 & $3.43-4.10$ & 3.80 & $\ldots$ & $\ldots$ \\
\hline Adult male ......... & $1.34-1.49$ & 1.40 & $3.89-5.18$ & 4.68 & $4.37-5.02$ & 4.79 \\
\hline Adult female........ & $1.35-1.51$ & 1.45 & $4.43-5.55$ & 4.99 & $4.78-5.35$ & 5.00 \\
\hline
\end{tabular}

hoppers is given in table 10. The males of Texananus lathropi required 56 to 62 days, an average of 59.5, to complete the nymphal stages; the females 63 to 72 days, an average of 66.4 . To reach the adult stage, the males of $T$. latipex required 47 to 59 days, an average of 52.6 ; the females 45 to 73 days, an average of 56.3. With both species of leafhoppers, the total duration of the nymphal stages is shorter for males than for females.

Measurements.-Table 11 gives the average measurements for various parts of the body of ten specimens one day after each molt, together with measurements for the adults of both leafhopper species. As shown by the mean measurements, the nymphal instars, males, and females of Texananus lathropi are larger than those of $T$. latipex. The males of the two species are smaller than the females. The instars can be determined accurately from the measurements of the head across the compound eyes.

Color of Nymphal Instars.-Recently hatched nymphs of both species are white with pink compound eyes. A few hours after hatching, the nymphs of 
both species become dark brown or black, with light areas of brown, yellow, and white that give them a mottled appearance (plate $2, A$ to $F$ ). The color patterns of the five instars of bath species are almost identical ; but, in general, the nymphs of Texananus latipex are darker than those of T. lathropi.

Color of Adults.-Adults of Texananus lathropi have a slight rosaceous tinge, a little more distinct on the elytrae than on the head and pronotum. Osborn and Lathrop (1923), who described the species, discuss the color pattern in detail. Two patterns occur with the males and females of T. latipexdark-brown and light-brown forms, mottled with white and black (plate 2, $G, H, I, J)$; details are given by DeLong (1943).

Mating.-An attempt was made to mate female Texananus lathropi with male $P$. latipex after the last molt, and female $T$. latipex with male $T$. lathropi. The experiment was repeated with 10 females of each species. Coition did not occur. Though eggs were deposited by some females, not a single nymph hatched. Evidently the two species will not cross or interbreed.

Preoviposition Period.-The period from the time the female reached the winged stage after the last molt until egg laying began was determined with each species. The preoviposition period of 2 females of Tenananus lathropi that passed through the last molt on January 17 and 20, was 40 and 44 days respectively. Two females that reached the winged stage on April 16 required 20 and 34 days. The preoviposition period of T. latipex that passed through the last molt on May 2 was 34 days ; May 4, 16 days; and May 6, 23 days.

Egg-laying Capacity.-To determine how many eggs a single female of Texananus lathropi deposits during her adult life, 1 female and 1 to 5 males after the last molt were confined in each cage enclosing a large healthy celery plant. When the celery became unfavorable as food, the female and males were transferred to a second plant-sometimes to a third. The eggs were allowed to hatch; and the total number of nymphs removed from each cage would equal the egg-laying capacity, provided all the eggs hatched. The nymphs were removed twice a month from each cage. The numbers that hatched from eggs deposited by each of 5 females were as follows : 229, 231, 345,369 , and 395 , or an average of 341 . The numbers that hatched from eggs deposited by each of 4 female T. latipex were as follows : 140, 171, 180, and 208 , or an average of 175 .

\section{VIRUS TRANSMISSION EXPERIMENTS WITH TEXANANUS SPATULATUS VAN DUZEE}

(Plate $3, C, D$ )

A study was undertaken on the possibility of transmitting the virus during the nymphal stages. To determine the efficiency of the vector, virus-transmission experiments were conducted with single males and females; varying numbers of adults were tested on healthy celery and asters, and upon successive asters. Attempts were made to determine the latent period of the virus in the adults, and the ability of this insect to transmit the viruses of curly top and Pierce's disease of grapevine.

The characters, distribution, and food plants of Texananus spatulatus have already been discussed by DeLong and Severin (1945). 


\section{EXPERIMENTAL METHODS}

In the transmission studies of the California aster-yellows virus, adults were used that had completed the nymphal stages on infected celery, and sometimes on asters. If leafhoppers were not reared, then the adults were fed on diseased celery for 10 days or longer to complete the latent period of the virus. Noninfective Texananus spatulatus were obtained by allowing females

TABLE 12

Transmission of Virus to Celery by Varying Numbers of Nymphs of Texananus spatulatus

\begin{tabular}{|c|c|c|c|c|c|c|}
\hline \multirow{2}{*}{$\begin{array}{c}\text { Number } \\
\text { of lots }\end{array}$} & \multirow{2}{*}{$\begin{array}{l}\text { Number of } \\
\text { nymphs in } \\
\text { each lot }\end{array}$} & \multirow{2}{*}{$\begin{array}{c}\text { Days on } \\
\text { infected } \\
\text { celery }\end{array}$} & \multirow{2}{*}{$\begin{array}{l}\text { Days on } \\
\text { healthy } \\
\text { celery }\end{array}$} & \multicolumn{3}{|c|}{ Celery } \\
\hline & & & & $\begin{array}{c}\text { Plants } \\
\text { iunoculated }\end{array}$ & $\begin{array}{c}\text { Plants } \\
\text { infected }\end{array}$ & $\begin{array}{l}\text { Per cent } \\
\text { infected }\end{array}$ \\
\hline \multicolumn{7}{|c|}{ Stadium I } \\
\hline 3 & 5 & 3 & 3 & 3 & 0 & 0.0 \\
\hline 2 & 5 & 4 & 4 & 2 & 0 & 0.0 \\
\hline 3 & 10 & 3 & 3 & 3 & 0 & 0.0 \\
\hline 2 & 10 & 4 & 4 & 2 & 0 & 0.0 \\
\hline
\end{tabular}

Stadium II

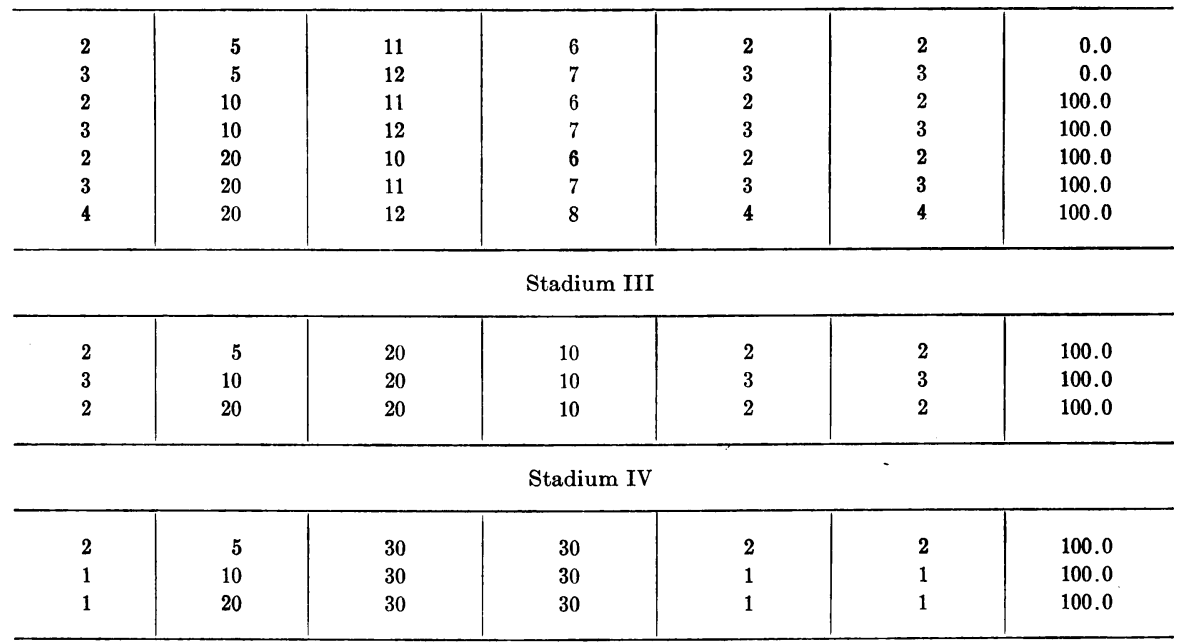

to oviposit in healthy sugar beets, immune to aster yellows; and the nymphs that hatched were transferred to healthy celery. Because sugar beets are not a favorable food plant of this insect, many nymphs failed to reach the adult stage.

\section{TRANSMISSION OF VIRUS TO CELERY}

By Varying Numbers of Nymphal Instars.-An experiment was conducted to determine whether each nymphal instar could transmit the virus. Lots consisting of varying numbers of each instar were fed during varying periods 
on infected and healthy celery. As the results show (table 12), the first instar was not able to transmit the virus, whereas each lot of the second (with 2 exceptions), third, and fourth instars infected healthy plants.

By Single Males and Females.-A comparison was made of the transmission of the virus by single male and female leafhoppers. After the adults had remained on diseased celery for 30 days, each leafhopper was fed on healthy celery until the plant manifested symptoms or until the insect died. As table 13 shows, 34 of 100 males and 29 of 100 females transmitted the virus to healthy plants.

By Varying Numbers of Adults.-A comparison was made of the infections produced by 5 males and 5 females that had completed the nymphal stages on diseased celery. Each lot of adults was transferred to a healthy celery

TABLE 13

Transmission of Virus to Celery by Varying Numbers of Adult

Texananus spatulatus

\begin{tabular}{|c|c|c|c|c|c|c|c|}
\hline \multirow{2}{*}{$\begin{array}{l}\text { Number } \\
\text { of lots }\end{array}$} & \multirow{2}{*}{$\begin{array}{l}\text { Number } \\
\text { of adults in } \\
\text { in each lot }\end{array}$} & \multicolumn{3}{|c|}{ First set of celery } & \multicolumn{3}{|c|}{ Second set of celery } \\
\hline & & $\begin{array}{c}\text { Plants } \\
\text { inoculated }\end{array}$ & $\begin{array}{c}\text { Plants } \\
\text { infected }\end{array}$ & $\begin{array}{l}\text { Per cent } \\
\text { infected }\end{array}$ & $\begin{array}{c}\text { Plants } \\
\text { inoculated }\end{array}$ & $\begin{array}{c}\text { Plants } \\
\text { infected }\end{array}$ & $\begin{array}{l}\text { Per cent } \\
\text { infected }\end{array}$ \\
\hline 100 & 1 male. & 100 & 34 & 34.0 & .. & . & $\ldots$ \\
\hline 100 & 1 female. & 100 & 29 & 29.0 & .. & .. & $\ldots$ \\
\hline 25 & 5 males. & 25 & 22 & 88.0 & 15 & 6 & 40.0 \\
\hline 25 & 5 females. . & '25 & 18 & 72.0 & 8 & 4 & 50.0 \\
\hline
\end{tabular}

plant and kept there until symptoms developed; then the surviving adults were transferred to a second healthy celery plant.

Table 13 shows the results obtained. The virus was transmitted to the first set of healthy celery by 22 of 25 lots of 5 males, or 88.0 per cent; and to 6 of 15 of the second set of plants, or 40 per cent. It was transmitted to the first set of celery by 18 of 25 lots of 5 females, or 72.0 per cent; and to 4 of 8 plants of the second set, or 50.0 per cent.

\section{TRANSMISSION OF VIRUS TO ASTERS ALTERNATING WITH CELERY}

$\Lambda$ comparison was made of the transmission of the virus to healthy asters and celery. Five lots of 40 males and 5 lots of 40 females, which had completed the nymphal stages on infected celery, were transferred daily or weekly to successive healthy asters alternating with celery (table 14).

The percentages of celery plants infected were as follows : daily, by males 28.7 per cent, by females 17.3 per cent; weekly, by males 80.0 per cent, by females 23.1 per cent. Since lower percentages of infections were obtained in daily than in weekly transfers, evidently the period of exposure of the leafhoppers on healthy celery is a factor in virus transmission. In daily and weekly transfers of the males and females, only 1 aster was infected, and that was by daily transfers of the males (table 14). 


\section{TRANSMISSION OF VIRUS TO ASTERS}

In the experiment on the transmission of the virus to asters alternating with celery in daily and weekly transfers, only 1 aster was infected of 188 inoculated (table 14). For this reason, the period of exposure on each aster was increased. Fifty lots of 5 males or 5 females that had completed the

TABLE 14

Transmission of Virus to Asters Alternating with Celery, by Adult Texananus spatulatus

\begin{tabular}{|c|c|c|c|c|c|c|c|}
\hline \multirow{2}{*}{$\begin{array}{l}\text { Number } \\
\text { of lots }\end{array}$} & \multirow{2}{*}{$\begin{array}{l}\text { Number of adults } \\
\text { in each lot }\end{array}$} & \multicolumn{3}{|c|}{ Asters } & \multicolumn{3}{|c|}{ Celery } \\
\hline & & $\begin{array}{c}\text { Plants } \\
\text { inoculated }\end{array}$ & $\begin{array}{c}\text { Plants } \\
\text { infected }\end{array}$ & $\begin{array}{l}\text { Per cent } \\
\text { infected }\end{array}$ & $\begin{array}{c}\text { Plants } \\
\text { inoculated }\end{array}$ & $\begin{array}{l}\text { Plants } \\
\text { infected }\end{array}$ & $\begin{array}{l}\text { Per cent } \\
\text { infected }\end{array}$ \\
\hline \multicolumn{8}{|c|}{ Daily inoculations } \\
\hline 5 & 40 males... & 79 & 1 & 1.3 & 80 & 23 & 28.7 \\
\hline 5 & 40 females. & 81 & 0 & 0.0 & 81 & 14 & 17.3 \\
\hline \multicolumn{8}{|c|}{ Weekly inoculations } \\
\hline 5 & 40 males.......... & 15 & 0 & 0.0 & 15 & 12 & 80.0 \\
\hline 5 & 40 females. . & 13 & 0 & 0.0 & 13 & 3 & 23.1 \\
\hline
\end{tabular}

TABLE 15

Transmission of Virus to Asters by Varying Numbers of Adult Texananus spatulatus

\begin{tabular}{|c|c|c|c|c|}
\hline $\begin{array}{l}\text { Number } \\
\text { of lots }\end{array}$ & Number of adults in each lot & $\begin{array}{c}\text { Plants } \\
\text { inoculated }\end{array}$ & $\begin{array}{l}\text { Plants } \\
\text { infected }\end{array}$ & $\begin{array}{l}\text { Per cent } \\
\text { infected }\end{array}$ \\
\hline 50 & 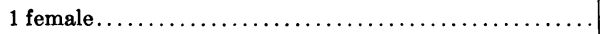 & 50 & 0 & 0.0 \\
\hline 25 & 5 males $\ldots \ldots \ldots \ldots \ldots \ldots \ldots \ldots \ldots \ldots \ldots \ldots \ldots \ldots \ldots \ldots \ldots$ & 25 & 2 & 8.0 \\
\hline 25 & 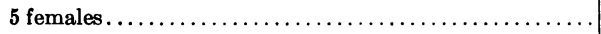 & 25 & 3 & 12.0 \\
\hline 5 & 40 females........... & 150 & 1 & 0.7 \\
\hline
\end{tabular}

nymphal stages on diseased celery were transferred and kept on healthy aster until they died. Two of 25 asters, or 8.0 per cent, were infected by lots of 5 males ; 3 of 25 asters, or 12 per cent, by lots of 5 females (table 15). Possibly if the adult life on asters had been longer, a higher percentage of infection would have resulted.

It was decided to rear the leafhoppers on diseased asters instead of celery. Ten lots of 40 males or females were transferred daily to successive healthy asters during adult life. One of 59 asters, or 1.7 per cent, was infected by the males; and 1 of 150 asters, or 0.7 per cent, by the females (table 15).

Fifty recently molted males and 50 females reared on infected asters were transferred singly to healthy asters. No aster yellows developed. 


\section{IATENT PERIOD OF VIRUS IN ADULTS}

The latent period of the virus was determined with lots of 40 males or females. After 1 day on infected celery, the adults were transferred daily to successive healthy celery plants throughout a period of 41 days. The mortality of the adults at the end of 42 days was recorded (table 16). The minimum latent period of the virus was 6 days; the maximum, 35 days. Only 18 of the 410 celery plants inoculated, or 4.4 per cent, became infected. This low percentage can be explained by the fact that each healthy plant was exposed to the adults for 1 day. One lot of males and 1 lot of females failed to transmit the virus.

TABLE 16

Latent Period of Virus in Adults of Texananus spatulatus with Celert AS THE HoST PLANT

\begin{tabular}{|c|c|c|c|c|c|}
\hline $\begin{array}{l}\text { Days on } \\
\text { infected } \\
\text { celery }\end{array}$ & $\begin{array}{l}\text { Successive } \\
\text { plants } \\
\text { inoculated }\end{array}$ & $\begin{array}{l}\text { Plants } \\
\text { infected }\end{array}$ & $\begin{array}{l}\text { Per cent } \\
\text { infected }\end{array}$ & $\begin{array}{l}\text { Days after transfer on which successive } \\
\text { infections occurred, including } \\
\text { initial day on infected celery }\end{array}$ & $\begin{array}{l}\text { Adults alive } \\
\text { at end of } \\
42 \text { days }\end{array}$ \\
\hline \multicolumn{6}{|c|}{ Four lots of 40 males each } \\
\hline $\begin{array}{l}1 \\
1 \\
1 \\
1\end{array}$ & $\begin{array}{l}41 \\
41 \\
41 \\
41\end{array}$ & $\begin{array}{l}3 \\
3 \\
1 \\
1\end{array}$ & $\begin{array}{l}7.3 \\
7.3 \\
2.4 \\
2.4\end{array}$ & 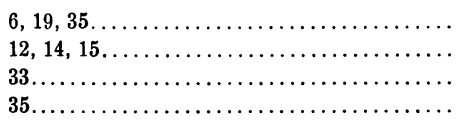 & $\begin{array}{l}29 \\
16 \\
21 \\
37\end{array}$ \\
\hline \multicolumn{6}{|c|}{ Four lots of 40 females each } \\
\hline $\begin{array}{l}1 \\
1 \\
1 \\
1\end{array}$ & $\begin{array}{l}41 \\
41 \\
41 \\
41\end{array}$ & $\begin{array}{l}3 \\
3 \\
2 \\
2\end{array}$ & $\begin{array}{l}7.3 \\
7.3 \\
4.9 \\
4.9\end{array}$ & $\begin{array}{l}17,18,29 \ldots \ldots \ldots \ldots \ldots \ldots \ldots \ldots \ldots \ldots \ldots \ldots \ldots \\
23,41,42 \ldots \ldots \ldots \ldots \ldots \ldots \ldots \ldots \ldots \ldots \ldots \ldots \\
16,19 . \ldots \ldots \ldots \ldots \ldots \ldots \ldots \ldots \ldots \ldots \ldots \ldots \ldots \ldots \\
18,27 \ldots \ldots \ldots \ldots \ldots \ldots \ldots \ldots \ldots \ldots \ldots \ldots\end{array}$ & $\begin{array}{l}22 \\
26 \\
30 \\
11\end{array}$ \\
\hline
\end{tabular}

\section{RETENTION OF VIRUS}

By Varying Numbers of Adults.-To determine whether a longer period of exposure on diseased celery is a factor in transmission of the virus by varying numbers of leafhoppers, lots of 20,10 , and 5 adults were kept on infected celery for 8 days and then were transferred daily to healthy celery for 34 days (table 17). Nine lots of 20 males and females infected 23 of 306 plants inoculated, or 7.5 per cent; 9 lots of 10 males and females infected 39 of 306 plants, or 12.4 per cent; and 4 lots of 5 males infected 4 of 136 plants, or 2.9 per cent. The latent period of the virus with lots of 20,10 , and 5 adults cannot be determined accurately: since the insects were kept on diseased celery for 8 days, it is not known whether they picked up the virus on the first day or later.

By Single Adults.--The retention of the virus was determined by use of single males and females, each of which had completed the nymphal stages on diseased celery. Each leafhopper was kept on a healthy celery plant until the latter showed symptoms; then the insect was transferred daily to successive healthy celery plants throughout its adult life. Table 18 shows the results. 
One male retained the virus for 84 days, and 1 female for 99 days. Seven males and 6 females produced only 1 infection. The first infection is not. included in the retention of the virus, since the adults were able to pick up the virus again.

\section{TABLE 17}

Retention of Virus by VARying Numbers of Adult Texananus spatulatus

\begin{tabular}{c|c|c|c|c|c|c|}
\hline $\begin{array}{c}\text { Number of } \\
\text { adults in } \\
\text { each lot }\end{array}$ & $\begin{array}{c}\text { Days on } \\
\text { infected } \\
\text { celery }\end{array}$ & $\begin{array}{c}\text { Successive } \\
\text { plants } \\
\text { inoculated }\end{array}$ & $\begin{array}{c}\text { Plants } \\
\text { infected }\end{array}$ & $\begin{array}{c}\text { Per cent } \\
\text { infected }\end{array}$ & $\begin{array}{c}\text { Days after transfer on which successive } \\
\text { infections occurred, including initial } \\
\text { day on infected celery }\end{array}$ & $\begin{array}{c}\text { at end of alive } \\
42 \text { days }\end{array}$ \\
\hline
\end{tabular}

Five lots of 20 males each

\begin{tabular}{|c|c|c|c|c|c|c|}
\hline 20 & 8 & 34 & 5 & 14.7 & $37,39,40,41,42 \ldots \ldots \ldots \ldots$ & 14 \\
\hline 20 & 8 & 34 & 3 & 8.8 & $9,11,15 \ldots \ldots \ldots \ldots \ldots \ldots \ldots \ldots \ldots \ldots$ & 6 \\
\hline 20 & 8 & 34 & 1 & 3.0 & 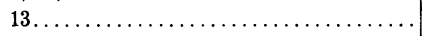 & 9 \\
\hline 20 & 8 & 34 & 1 & 3.0 & $25 \ldots \ldots \ldots \ldots \ldots \ldots \ldots \ldots \ldots \ldots$ & 7 \\
\hline 20 & 8 & 34 & 1 & 3.0 & 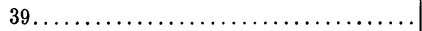 & 9 \\
\hline
\end{tabular}

Four lots of 20 females each

\begin{tabular}{|c|c|c|c|c|c|c|}
\hline 20 & 8 & 34 & 6 & 17.6 & $16,24,26,32,34,36 \ldots \ldots \ldots \ldots \ldots \ldots$ & 9 \\
\hline 20 & 8 & 34 & 2 & 5.9 & $12,41 \ldots \ldots \ldots \ldots \ldots \ldots \ldots \ldots \ldots \ldots \ldots$ & 17 \\
\hline
\end{tabular}

Five lots of 10 males each

\begin{tabular}{|c|c|c|c|c|c|c|}
\hline 10 & 8 & 34 & 12 & 35.3 & $10,11,17,23,24,29,30,33,34,37,39,42 \ldots$ & 8 \\
\hline 10 & 8 & 34 & 7 & 20.6 & $14,30,31,32,34,38,40 \ldots \ldots \ldots \ldots$ & 10 \\
\hline 10 & 8 & 34 & 5 & 14.7 & $9,10,38,40,41 \ldots \ldots \ldots \ldots$ & 8 \\
\hline 10 & 8 & 34 & 4 & 11.8 & $22,23,33,35 \ldots \ldots \ldots \ldots \ldots \ldots \ldots \ldots \ldots$ & 4 \\
\hline 10 & 8 & 34 & 3 & 8.8 & $25,28,35 \ldots \ldots \ldots \ldots \ldots \ldots$ & 6 \\
\hline
\end{tabular}

Four lots of 10 females each

\begin{tabular}{|c|c|c|c|c|c|c|}
\hline $\begin{array}{l}10 \\
10 \\
10 \\
10\end{array}$ & $\begin{array}{l}8 \\
8 \\
8 \\
8\end{array}$ & $\begin{array}{l}34 \\
34 \\
34 \\
34\end{array}$ & $\begin{array}{l}4 \\
2 \\
1 \\
1\end{array}$ & $\begin{array}{r}11.8 \\
5.9 \\
3.0 \\
3.0\end{array}$ & 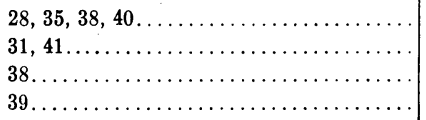 & $\begin{array}{l}9 \\
6 \\
6 \\
5\end{array}$ \\
\hline \multicolumn{7}{|c|}{ Four lots of 5 males each } \\
\hline 5 & 8 & 34 & 1 & 3.0 & $9 \ldots \ldots \ldots \ldots$ & 4 \\
\hline 5 & 8 & 34 & 1 & 3.0 & $30 \ldots$ & 3 \\
\hline 5 & 8 & 34 & 1 & 3.0 & $32 \ldots$ & 3 \\
\hline 5 & 8 & 34 & 1 & 3.0 & $39 \ldots$ & 5 \\
\hline
\end{tabular}

\section{ATTEMPTS TO TRANSMIT VIRUSES OF CURLY TOP AND PIERCE'S DISEASES OF GRAPEVINE}

An attempt was made to transmit the curly-top virus by means of Texananus spatulatus. Fifteen lots of 5 to 20 males or females reared during the nymphal stages on nettleleaf goosefoot (sowbane), Chenopodium murale, were exposed to curly-top beets for periods varying from 2 to 14 days; and then each lot was transferred to a healthy beet. All beets remained healthy. 
An attempt was made to transmit and recover the curly-top virus from susceptible host plants on which Texananus spatulatus were collected in the field. Noninfective leafhoppers after feeding on 2 nettleleaf goosefoot plants and 2 rough pigweeds, Amaranthus retroflexus, inoculated by infective beet leafhoppers, failed to recover the virus and transmit it to healthy sugar beets.

In another test 135 adults collected on pasture vegetation on the summit of Pacheco Pass on May 5, 1942, were distributed on 3 curly-top beets and kept

TABLE 18

Retention of Virus by Single Adults of Texananus spatulatus with Celery as the Host Plant

\begin{tabular}{c|c|c|c|c|c}
\hline $\begin{array}{c}\text { Days on } \\
\text { first plant } \\
\text { before }\end{array}$ & $\begin{array}{c}\text { Plants } \\
\text { inoculated } \\
\text { after } \\
\text { fymptoms } \\
\text { developed }\end{array}$ & $\begin{array}{c}\text { Plants } \\
\text { infected } \\
\text { infection }\end{array}$ & $\begin{array}{c}\text { after } \\
\text { first } \\
\text { infection }\end{array}$ & $\begin{array}{c}\text { Per cent } \\
\text { after } \\
\text { first } \\
\text { infection }\end{array}$ & $\begin{array}{c}\text { Days after first infection } \\
\text { on which successive } \\
\text { infections occurred }\end{array}$ \\
\hline
\end{tabular}

Ten lots of single males

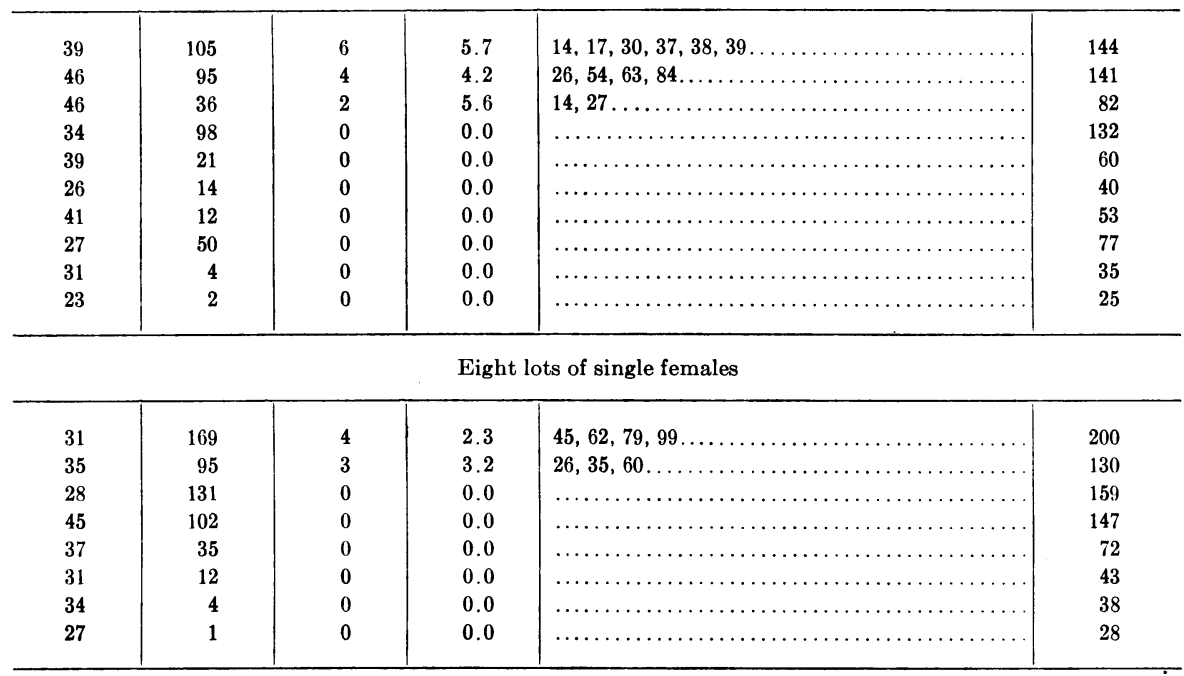

there for 2 days; then each lot was transferred to a healthy sugar beet. All beets remained healthy.

Lots of 20 adults of Texananus spatulatus, after feeding on Pierce's disease of grapevines, failed to transmit the virus to 6 healthy grapevines and 5 common or Chilean alfalfa plants, and from alfalfa dwarf to 5 healthy grapevines and to 5 alfalfa plants.

There was no evidence to show that the beet leafhopper, Eutettix tenellus (Bakers), could transmit the curly.top virus to healthy grapevines. Severin (1928) demonstrated that Hairy Peruvian alfalfa, Medicago sativa L., was naturally and has been experimentally infected with curly top. The beet leafhopper failed to transmit the virus of Pierce's disease of grapevine to healthy grapevines and alfalfa. 


\section{TEXANANUS PERGRADUS DELONG AS A VECTOR (Plate $3, E, F^{\prime}$ )}

This phlepsid leafhopper has been collected on a variety of food plants, as shown by DeLong and Severin (1945). It has been reared on celery infected with aster yellows, but few nymphs reached the adult stage.

Adults that completed the nymphal stages on infected celery were transferred singly to healthy celery. If symptoms of the disease developed, the insects were fed on one or more additional plants. Single males and females each transferred to one or more healthy celery plants transmitted the virus to 5 of 14 and 11 of 22 plants respectively (table 19). In other tests, adults collected in the field were kept on infected celery for 10 days or longer to complete the latent period of the virus, before transferring to healthy plants. Lots of 2 to 10 adults infected 12 of 31 plants inoculated as shown in table 19.

TABLE 19

Transmission of Virus to Celery by Varying Numbers of Adult Texananus oregonus

\begin{tabular}{|c|c|c|c|c|c|c|c|c|c|}
\hline \multicolumn{5}{|c|}{ Males } & \multicolumn{5}{|c|}{ Females } \\
\hline $\begin{array}{c}\text { Number } \\
\text { of } \\
\text { lots }\end{array}$ & $\begin{array}{c}\text { Number } \\
\text { of adults } \\
\text { in each lot }\end{array}$ & $\begin{array}{c}\text { Plants } \\
\text { inoculated }\end{array}$ & $\begin{array}{l}\text { Plants } \\
\text { infected }\end{array}$ & $\begin{array}{l}\text { Per cent } \\
\text { infected }\end{array}$ & $\begin{array}{c}\text { Number } \\
\text { of } \\
\text { lots }\end{array}$ & $\begin{array}{l}\text { Number } \\
\text { of adults } \\
\text { in each lot }\end{array}$ & $\begin{array}{c}\text { Plants } \\
\text { inoculated }\end{array}$ & $\begin{array}{c}\text { Plants } \\
\text { infected }\end{array}$ & $\begin{array}{l}\text { Per cent } \\
\text { infected }\end{array}$ \\
\hline 8 & 1 & 14 & 5 & 35.7 & 11 & 1 & 22 & 11 & 50.0 \\
\hline 1 & 2 & 7 & 1 & 14.3 & 1 & 2 & 12 & 2 & 16.7 \\
\hline 1 & 3 & 1 & 1 & 100.0 & 2 & 3 & 2 & 1 & 50.0 \\
\hline 4 & 10 & 4 & 4 & 100.0 & 2 & 5 & 4 & 2 & 50.0 \\
\hline .. & .. & .. & .. & $\ldots \ldots$ & 1 & 10 & 1 & 1 & 100.0 \\
\hline
\end{tabular}

\section{TEXANANUS PERGRADUS DELONG AS A VECTOR}

\section{(Plate $3, G, H$ )}

This leafhopper was reared on celery infected with aster yellows from 12 males and 14 females collected on May 4, 1940, on pasture vegetation along a riverbank at Woodlake, Tulare County. The characters, distribution, and food plants are reported by DeLong and Severin (1945).

Fifty males and 50 females tested singly on healthy celery failed to cause infection, but 1 aster was infected by 1 of 50 males as is shown in table 20 . Twelve lots of 10, 25 lots of 20 , and 5 lots of 40 males produced 1, 5, and 1 infections as indicated in table 20.

\section{PHLEPSIUS APERTINUS OSBORN AND LATHROP AS A VECTOR}

\section{(Plate $3, A, B$ )}

This leafhopper is common in alfalfa fields. The characters, distribution, and food plants have been discussed by DeLong and Severin (1945). The insect has not been reared on any host plant up to the present time.

Adults collected in the field were kept on diseased celery for 10 days or 
TABLE 20

Transmission of Virus to Celery and Asters by Varying Numbers of Adult Texananus pergradus

\begin{tabular}{|c|c|c|c|c|c|c|c|c|c|}
\hline \multicolumn{5}{|c|}{ Males } & \multicolumn{5}{|c|}{ Females } \\
\hline $\begin{array}{c}\text { Number } \\
\text { of } \\
\text { lots }\end{array}$ & $\begin{array}{l}\text { Number } \\
\text { of adults } \\
\text { in each lot }\end{array}$ & $\begin{array}{c}\text { Plants } \\
\text { inoculated }\end{array}$ & $\begin{array}{c}\text { Plants } \\
\text { infected }\end{array}$ & $\begin{array}{l}\text { Per cent } \\
\text { infected }\end{array}$ & $\begin{array}{c}\text { Number } \\
\text { of } \\
\text { lots }\end{array}$ & $\begin{array}{c}\text { Number } \\
\text { of adults } \\
\text { in each lot }\end{array}$ & $\begin{array}{c}\text { Plants } \\
\text { inoculated }\end{array}$ & $\begin{array}{c}\text { Plants } \\
\text { infected }\end{array}$ & $\begin{array}{l}\text { Per cent } \\
\text { infected }\end{array}$ \\
\hline \multicolumn{10}{|c|}{ Celery } \\
\hline 50 & 1 & 50 & 0 & 0.0 & 50 & 1 & 50 & 0 & 0.0 \\
\hline 12 & 5 & 12 & 0 & 0.0 & 2 & 5 & 2 & 0 & 0.0 \\
\hline 12 & 10 & 12 & 1 & 8.3 & 1 & 10 & 1 & 0 & 0.0 \\
\hline 25 & 20 & 25 & 5 & 20.0 & 3 & 20 & 3 & 0 & 0.0 \\
\hline 5 & 40 & 48 & 1 & 2.1 & 5 & 40 & 45 & 0 & 0.0 \\
\hline \multicolumn{10}{|c|}{ Asters } \\
\hline 2 & 40 & 50 & 1 & 2.0 & 2 & 40 & 60 & 0 & 0.0 \\
\hline
\end{tabular}

\section{TABLE 21}

Transmission of Virus to Celery by Varying Numbers of Adult Phlepsius apertinus

\begin{tabular}{|c|c|c|c|c|c|c|c|c|c|}
\hline \multicolumn{5}{|c|}{ Males } & \multicolumn{5}{|c|}{ Females } \\
\hline $\begin{array}{c}\text { Number } \\
\text { of } \\
\text { lots }\end{array}$ & $\begin{array}{c}\text { Number } \\
\text { of adults } \\
\text { in each lot }\end{array}$ & $\begin{array}{c}\text { Plants } \\
\text { inoculated }\end{array}$ & $\begin{array}{c}\text { Plants } \\
\text { infected }\end{array}$ & $\begin{array}{l}\text { Per cent } \\
\text { infected }\end{array}$ & $\begin{array}{c}\text { Number } \\
\text { of } \\
\text { lots }\end{array}$ & $\begin{array}{l}\text { Number } \\
\text { of adults } \\
\text { in each lot }\end{array}$ & $\begin{array}{c}\text { Plants } \\
\text { inoculated }\end{array}$ & $\begin{array}{c}\text { Plants } \\
\text { infected }\end{array}$ & $\begin{array}{l}\text { Per cent } \\
\text { infected }\end{array}$ \\
\hline 9 & 1 & 13 & 7 & 53.8 & 10 & 1 & 14 & 8 & 57.1 \\
\hline 1 & 2 & 1 & 0 & 0.0 & 1 & 5 & 2 & 0 & 0.0 \\
\hline 1 & 5 & 1 & 0 & 0.0 & 1 & 6 & 2 & 1 & 50.0 \\
\hline 1 & 9 & 1 & 1 & 100.0 & 9 & 20 & 12 & 5 & 41.7 \\
\hline 1 & 10 & 1 & 1 & 100.0 & 1 & 25 & 5 & 1 & 20.0 \\
\hline 1 & 12 & 2 & 2 & 100.0 & 1 & 30 & 1 & 1 & 100.0 \\
\hline 1 & 13 & 2 & 0 & 0.0 & .. & .. & .. & .. & $\ldots$. \\
\hline 1 & 14 & 3 & 2 & 66.7 & .. & .. & .. & .. & $\ldots \ldots$ \\
\hline 1 & 15 & 1 & 0 & 0.0 & .. & .. & .. & .. & $\ldots \ldots$ \\
\hline 3 & 20 & 3 & 0 & 0.0 & .. & .. & .. & .. & $\ldots$. \\
\hline
\end{tabular}

longer to complete the latent period of the virus. Males and females tested singly on healthy celery plants transmitted the virus to 7 of 13, and 8 of 14 plants respectively. Lots of 2 to 30 adults produced 14 infections as shown in table 21. 


\section{SUMMARY}

Six newly demonstrated vectors of the California aster-yellows virus are reported in this paper; this proves that the virus is not transmitted by a specific leafhopper.

Texananus lathropi and T. latipex: The infections produced by 150 males and 150 females of $T$. lathropi, each kept singly on a healthy celery plant, was 18.7 and 16.0 per cent respectively, and by 100 males and 100 females of T. latipex was 18.0 and 32 per cent respectively.

Lots of 40 males or females of both leafhopper species, placed on celery alternating with asters, caused lower percentages of infections in celery in daily than in weekly transfers, a fact indicating that the period of exposure of healthy celery to the leafhoppers affects virus transmission. Lower percentages of infections occurred with asters than with celery; and, with one exception, lower percentages of asters were infected in daily than in weekly transfers. Higher percentages of infections occurred with 6 successive asters inoculated by Texananus latipex every 3 weeks than in daily inoculations or, with one exception, weekly inoculations-a fact again demonstrating that the period of exposure of asters to leafhoppers influences virus transmission.

Since there was an increase in the percentages of infections in celery with lots of 5,10 , and 20 adults, apparently the number of leafhoppers play a role in virus transmission.

The minimum latent period of the virus in the males and females of Texananus lathropi was 7 and 8 days respectively; in T. latipex with 1 lot of 80 males it was 8 days. The maximum latent period in T. lathropi was 33 days; in T. latipex, 37 days.

The virus was retained by single adults of Texananus lathropi from 5 to 77 days and by T. latipex from 1 to 42 days after the first infection was produced. Many of the leafhoppers of both species caused only 1 infection each.

Attempts to transmit the viruses of curly top and Pierce's disease of grapevine by means of the two species of leafhoppers were failures.

Life history studies were made of the egg periods, egg-laying capacity, and duration of the nymphal instars.

Texananus spatulatus: The aster-yellows virus was not transmitted by the first nymphal instar; probably the latent period of the virus was not completed. All other nymphal instars transmitted the virus.

Single males infected 34 per cent of the celery, and single females 29 per cent. Lots of 5 males transmitted the virus to 88.00 per cent and lots of 5 females to 72.0 per cent of the first set of celery and to 40.0 and 50.0 per cent of the second set respectively.

Lots of 40 males and 40 females infected 28.7 and 17.3 per cent respectively in daily transfers to successive celery plants, and 80.0 and 23.1 per cent in weekly transfers. Only 0.6 per cent of the asters were infected in daily transfers and none in weekly transfers to successive asters.

Lots of 5 males and 5 females kept on asters during adult life infected 8.0 and 12.0 per cent of the asters respectively. Lots of 40 males and 40 females reared on diseased asters infected 1.7 and 0.7 per cent, respectively, in daily transfers to successive asters. 
The latent period of the virus in the adults was 6 to 42 days.

One male retained the virus for 84 days, and one female 99 days. Most adults caused one infection and then apparently lost the infective dose.

All attempts to transmit the curly-top virus by means of Texananus spatulatus were failures. The leafhopper did not recover the virus from susceptible host plants on which they were collected in the field, such as Chenopodium murale and Amaranthus retroflexus, and transmit it to healthy sugar beets. This leafhopper failed to transmit the virus of Pierce's disease of grapevine and alfalfa dwarf to healthy grapevine seedlings and alfalfa.

There was no evidence that the beet leafhopper could transmit the curlytop virus to healthy grapevine seedlings or the virus of Pierce's disease of grapevine to healthy grapevines and alfalfa.

T'exananus oregonus: Males and females tested singly on healthy celery infected 5 of 14 plants and 11 of 22 plants respectively. Lots of 2 to 10 adults infected 18 to 34 plants inoculated.

T'exananus pergradus: 100 males and females kept singly on healthy celery caused no infections, but 1 aster was infected by 1 of 50 males. Twelve lots of 10, 25 lots of 20 , and 5 lots of 40 males produced 1, 5, and 1 infection.

Phlepsius apertinus: With this species, 13 males and 12 females infected 7 of 13 and 8 of 14 celery plants respectively. Lots of 2 to 30 adults produced 14 infections.

\section{ACKNOWLEDGMENT}

Thanks are due to J. S. Lilley, who did part of the preliminary work on the life histories of Texananus lathropi and T'. latipex. Mr. Lilley also conducted some of the experiments on daily and weekly transfers of the leafhoppers to celery and asters, and on the retention of the virus. 


\section{LITERATURE CITED}

AввотT, E. V., and J. W. INGRAM.

1942. Transmission of chlorotic streak of sugar cane by the leafhopper, Draeculacephala portola. Phytopathology 32(1):99-100.

Agati, A. A., P. L. Sison, and R. Abalos.

1941. A progress report on the rice maladies recently observed in central Luzon with special reference to the stunt or dwarf disease. Philippine Jour. Agr. 12(2): 197-210.

BALL, E. D.

1906. Beet leafhopper (Eutettix tenella). Utah Agr. Exp. Sta. Ann. Rept. 1904-1905:16.

1909. The leafhoppers of the sugar beet and their relation to curly-leaf condition. U. S. Dept. Agr. Bur. Ent. Bul. 66 (Pt. 4) :31-52.

BAWDEN, F. C.

1943. Plant viruses and virus diseases. Second revised edition. 294 p. Chronica Botanica Co., Waltham, Mass.

BLACK, L. M.

1937. A study of potato yellow dwarf in New York. New York (Cornell) Agr. Exp. Sta. Mem. 209:1-23.

1941. Specific transmission of varieties of potato yellow-dwarf virus by related insects. Amer. Potato Jour. 18(8) :231-33.

1944. Some viruses transmitted by Agallian leafhoppers. Amer. Phil. Soc. Proc. 88: $132-44$.

BRANDES, E. W.

1920. Artificial and insect transmission of sugar-cane mosaic. Jour. Agr. Research 19: 131-38.

California Agricultural Experiment Station.

1928. California Agricultural Experiment Station Annual Report. 1927-28:75-76.

Chardon, C. E., and R. E. Veve.

1922. Sobre la transmisón del matizádo se la caña por medio de insectos. Rev. Agr. Puerto Rico 9(2):9-20.

DAvis, E. W.

1927. Notes on the collection of the sugar beet leafhopper showing extensions of its known host range in British Columbia and to the coast in Washington and Oregon. Jour. Econ. Ent. 20:581-86.

DELONG, D. M.

1942. The North American species of the subfamily Gyponinae. The Ohio State University. Graduate School monograph series. Contribution in Zoology and Entomology No. 5:1-187.

1943. Three new species of Texananus from the western and southwestern United States. Brooklyn Ent. Soc. 38:124-27.

DeLong, D. M., and H. H. P. Severin.

1945. Characters, distribution, and food plants of phlepsid leafhopper vectors of California aster-yellows virus. Hilgardia 17 (1) :1-20.

DoBRosckY, I. D.

1929. Cranberry false-blossom disease spread by a leafhopper. Science 70:635.

1931. Cranberry false-blossom disease and its insect vector. Boyce Thompson Inst. Contrib. 3:59-83.

FAWCETT, G. L.

1925. Encrespamiento de las hojas de la remolacha azucarera. Rev. Indus. y Agr. de Tucumán 16:39-46.

1927. The curly top of the sugar beet in the Argentine Republic. Phytopathology 13: 458-60.

Frazier, N. W.

1945. Phylogenetic relationship of the nine leafhopper vectors of Pierce's disease of grape. (Abstract.) Phytopathology 34:1000-01. 
Furushi, T.

1937. An insect vector of dwarf disease of rice. [In Japanese.] Imp. Acad. Japan Proc. $13(8): 328-31$.

Hewite, W. B., N. W. Frazier, and B. R. Houston.

1942. Transmission of Pierce's disease of grapevines with a leafhopper. Phytopathology $32: 8$.

Hewitt, W. B., N. W. Frazier, H. E. Jacobs, and J. H. Freitag.

1942. Pierce's disease of grapevines. California Agr. Exp. Sta. Cir. 353:1-32.

HiLL, A. V.

1937. Big bud of tobacco. Austral. Council Sci. \& Indus. Res. Jour. 10:309-12.

1941. Yellow dwarf of tobaceo. Austral. Council Sci. \& Indus. Res. Jour. 14 (3) :181-86.

1943. Insect transmission and host plants of virescence (big bud of tomato). Austral. Council Sci. \& Indus. Res. Jour. 16(2) :85-90.

INGRAM, J. W.

1937. Insects that carry mosaic disease of sugarcane. Sugar Bul. 16(6):4-7.

Ingram, J. W., E. Haley, and L. J. Charpentier.

1939. Insect vectors of sugarcane mosaic in continental United States. Sixth Cong. Internatl. Soc. Sugar Cane Technol. Proc. 1938:483-94.

INGRAM, J. W., and E. M. SUMMERS.

1936. Transmission of sugarcane mosaic by the rusty plum aphid, Hysteroneura setariae. Jour. Agr. Res. 52:879-88.

1938. Transmission of sugarcane mosaic by the green bug (Toxoptera graminum). Jour. Agr. Research 56(7):537-40.

IsHIKAWA, $\mathrm{T}$.

1928. The merit of Hatsuzo Hashimoto, the earliest investigator of stunt disease of rice plant. [In Japanese.] Nippon Plant Protect. Soc., Jour. Plant Protect. (Byochugai Zasshi) 15:218-22.

KATSURA, S.

1936. The stunt disease of Japanese rice, the first virosis shown to be transmitted by an insect vector. Phytopathology $26: 887-95$.

KUNKEL, L. O.

1922. Insect transmission of yellow stripe disease. Hawaii Planters Rec. 58-64.

1926. Studies on aster yellows. Amer. Jour. Bot. 13:646-705. Also in: Boyce Thompson Inst. Contrib. 1:181-240.

1933. Insect transmission of peach yellows. Boyce Thompson Inst. Contrib. 5:19-28.

1944. Plant viruses. Science 99(2579):450-451. [A review of: Plant viruses and virus diseases, by F. C. Bawden. 2d ed. Chronica Botanica Company, Waltham, Mass. 1943.]

LEACH, J. G.

1940. Insect transmission of plant diseases. 615 p. MeGraw-Hill Book Co., New York and London.

MEDLER, J. T.

1942. The leafhoppers of Minnesota. Minnesota Agr. Exp. Sta. Tech. Bull. 155:1-196.

Menzies, J. D.

1944. Transmission studies with alfalfa witches'-broom. Phytopathology $34: 936$.

OMAN, P. W.

1934. South American leafhoppers of the genus Agalliana. Rev. de Ent. 4(3) :333-40.

OSBORN, H., and F. H. LATHROP.

1923. The genus Phlepsius in North America. Ann. Ent. Soc. Amer. 16:310-62.

RYJKOFF, V. L.

1935. Filterable virus as a cause of virescence of flowers. Rev. Appl. Mycol. 14:130-31. RYJKoFF, V. L., and I. K. KaRATChevsky.

1935. Experiments on the artificial transmission of virus diseases of tomato. Abstracted in: Rev. Appl. Mycol. 14:130. 
SCHINDLER, A. J.

1942. Insect transmission of Wallaby ear disease of maize. Austral. Inst. Agr. Sci. Jour. $8(1): 35-7$.

SEverin, H. H. P.

1921. Mininum incubation periods of causative agent of curly leaf in beet leafhopper and sugar beet. Phytopathology $11: 424-29$.

1929. Yellows disease of celery, lettuce, and other plants, transmitted by Cicadula sexnotata (Fall.). Hilgardia 3(18): 543-83.

1930. Life-history of beet leafhopper, Eutettix tenellus (Baker), in California. Univ. California Pubs. Ent. 5:37-88.

1931. Modes of curly-top transmission by the beet leafhopper, Eutettix tenellus (Baker). Hilgardia 6(8) :253-76.

1933. Field observations of the beet leafhopper, Eutettix tenellus, in California. Hilgardia $7(8): 281-360$.

1934. Transmission of California aster and celery-yellows virus by three species of leafhoppers. Hilgardia 8(10):339-62.

1940. Potato naturally infected with California aster yellows. Phytopathology $30(12)$ : 1049-51.

1942. Infection of perennial delphiniums by California aster-yellows virus. Hilgardia $14(8): 411-40$.

Severin, H. H. P., and F. A. HaAsis.

1934. 'Transmission of California aster yellows to potato by Cicadula divisa. Hilgardia $8(10): 329-35$.

Severin, H. H. P., and C. F. Henderson.

1928. Beet leafhopper, Eutettix tenellus (Baker), does not occur in the Argentine Republic. Jour. Econ. Ent. 21 (4) :542-44.

1928. Some host plants of curly top. Hilgardia 3(13):339-93.

SHAw, H. B.

1910. The curly-top of beets. U. S. Dept. Agr. Bur. Plant Indus. Bul. 181:1-46.

SмITH, K. M.

1937. A textbook of plant virus diseases. 615 p. P. Blakiston's Son \& Co., Inc., Philadelphia, Penn.

SMITH, R. E., and P. A. BoncQUeT.

1915. Connection of a bacterial organism with curly leaf of the sugar beet. Phytopathology $5: 335-42$.

STOREY, H. H.

1925a. The transmission of streak disease of maize by the leafhopper, Balclutha mbila Naude. Ann. Appl. Biol. $12: 422-39$.

1925b. Streak disease of sugar cane. Union So. Africa Dept. Agr. Sci. Bul. 39:1-30.

1926. Interspecific cross-transmission of plant virus diseases. So. African Jour. Sci. 23:305-06.

1928. Transmission studies of maize streak disease. Ann. Appl. Biol. 15:1-25.

1937. A new virus of maize transmitted by Cicadulina spp. Ann. Appl. Biol. 24:87-94.

1939. Transmission of plant viruses. Bot. Rev. $5: 240-72$.

STOREY, H. H., and A. P. D. MCLeAN.

1930. The transmission of streak disease between maize, sugar eane, and wild grasses. Ann. Appl. Biol. 17(4) :692-719.

TAKATA, K.

1895-96. Results of experiments with the dwarf disease of rice. [In Japanese.] Jour. Japan. Agr. Soc. 171:1-4, 13-32.

TATE, H. B., and S. R. VANDERBERG.

1939. Transmission of sugarcane mosaic by aphids. Jour. Agr. Research 59:73-79.

THomas, K. M., and C. S. KRIShNaSWami.

1939. Little leaf-a transmissible disease of Brinjal. Indian Acad. Sci. Proc. 10(2): 201-12.

WALKER, J. C., and R. H. LARSON.

193א. Yellow dwarf of potato in Wisconsin. Jour. Agr. Research $59: 259-80$. 

PLATES 



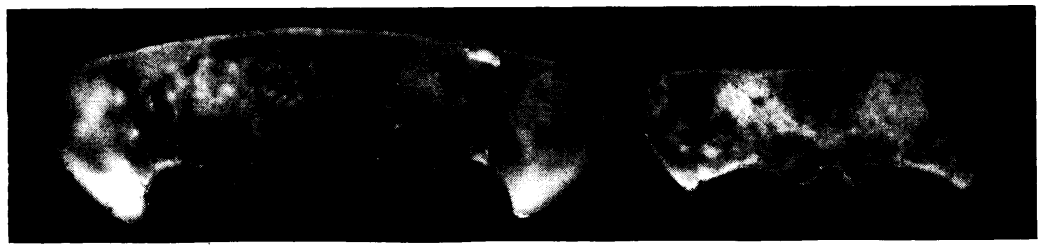

$A$

$B$

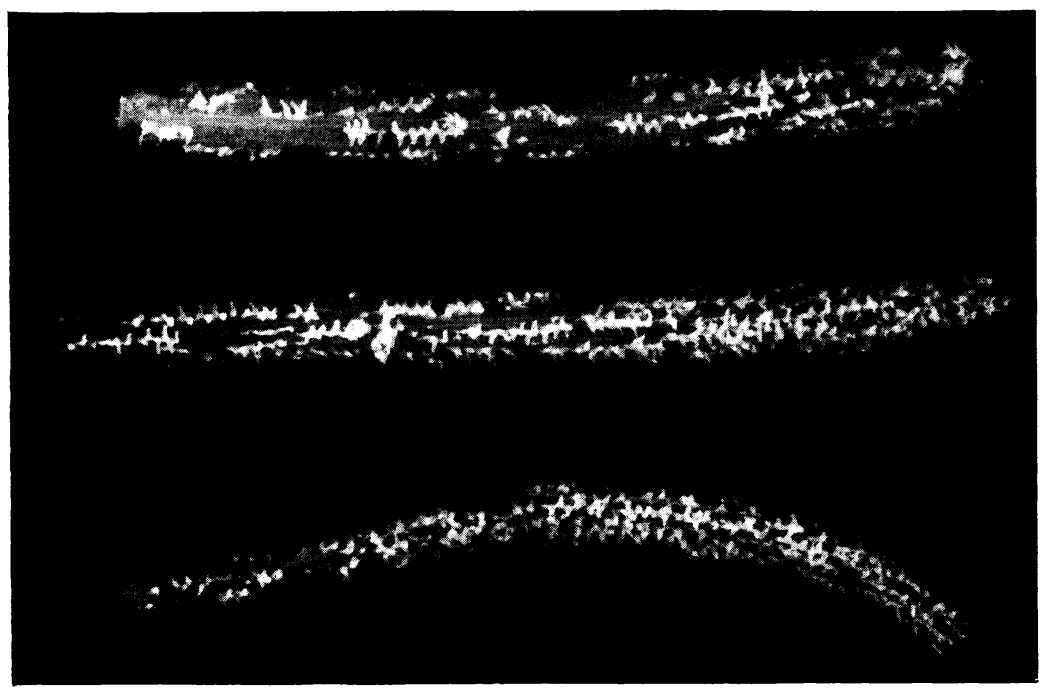

\section{C}

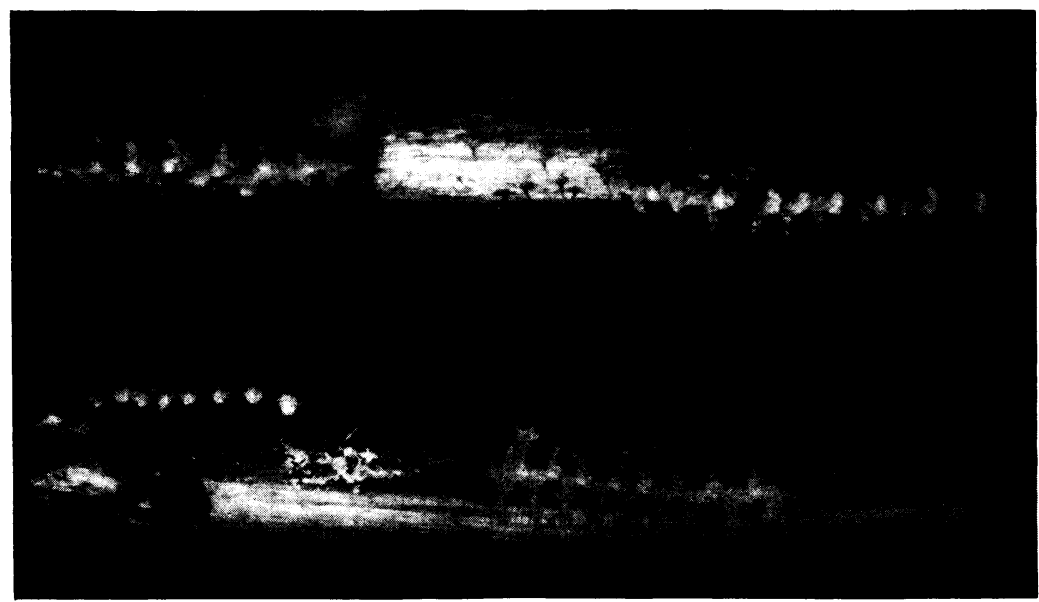

\section{$D$}

Plate 1.-A, Last sternite of female Texananus lathropi Baker, showing U-shaped indentation that extends halfway through the last ventral segment; $B$, last sternite of female T. latipex DeLong, showing V-shaped indentation of the posterior margin of the last ventral segment; C, white papillae covering the egg punctures of $T$. lathropi in the petioles of celery; $D$, papillae (enlarged) covering alternating egg punctures in two opposite rows. 

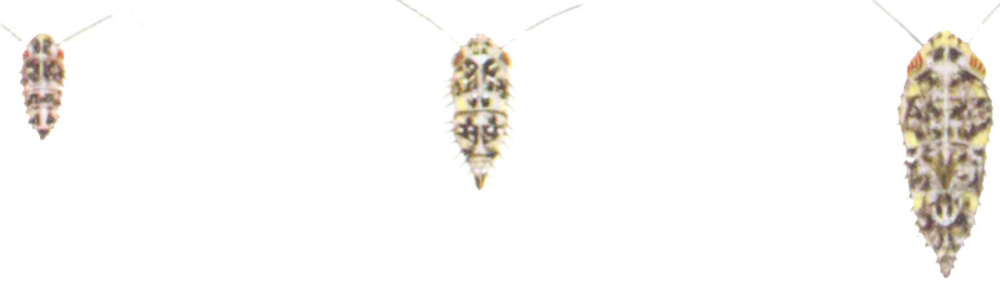

C
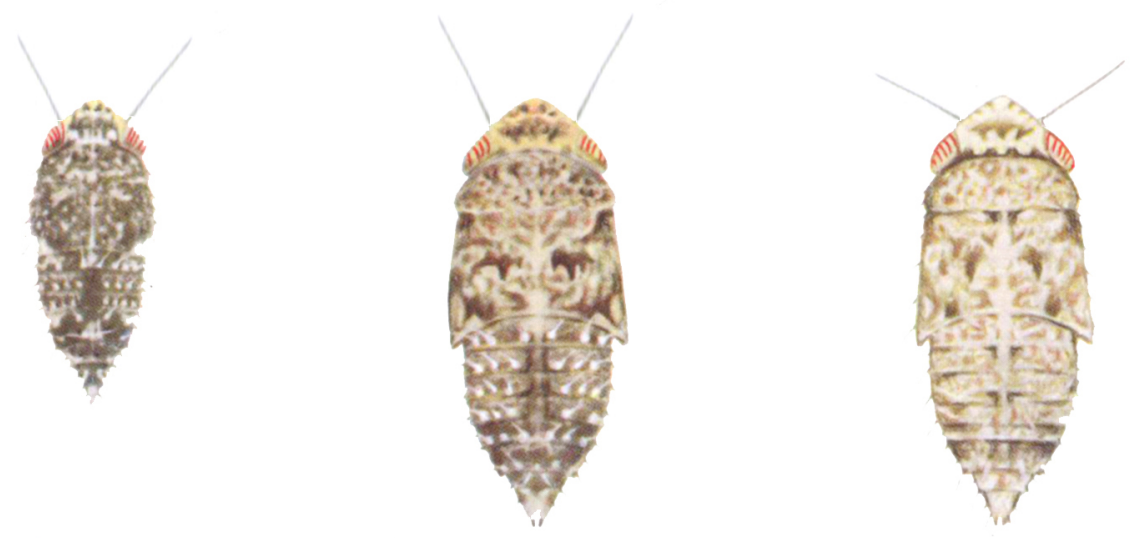

D

E

F

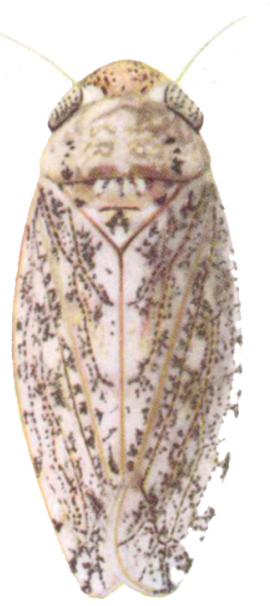

G

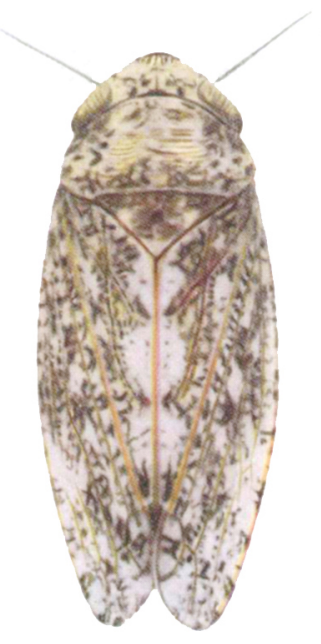

H

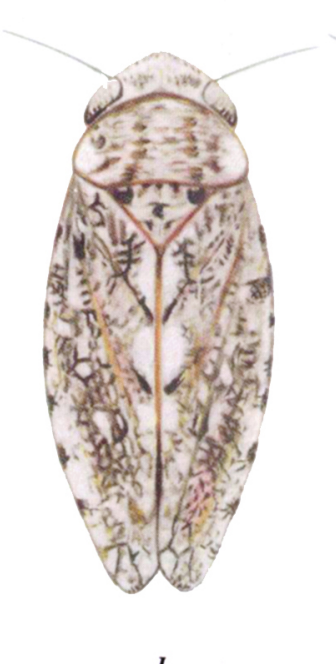

I

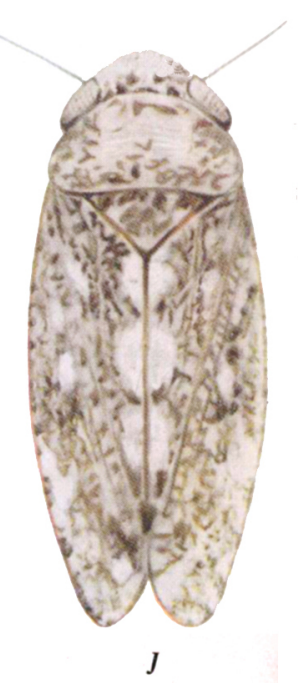

Plate 2.-Color patterns of nymphal instars and adults of T'exananus latipex DeLong: A, B, C, D, E. first to fifth nymphal instars; $F$, brown fifth instar, paler than fifth instar $E ; G$, male, $H$, female, dark forms; $I$, male, $J$, female, hyaline forms. 


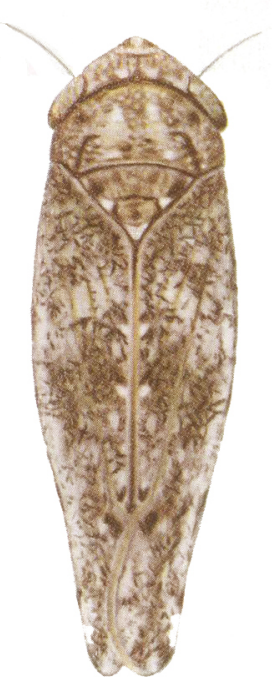

$A$

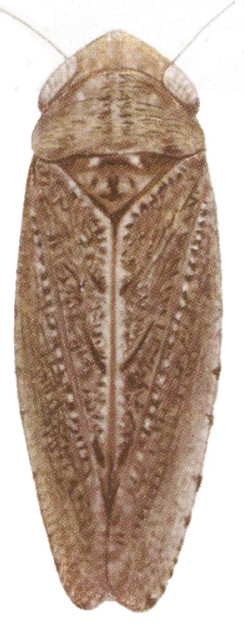

$E$

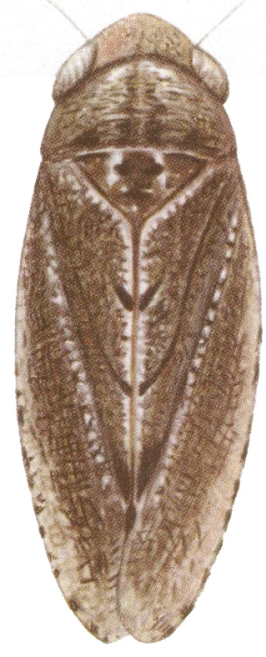

F

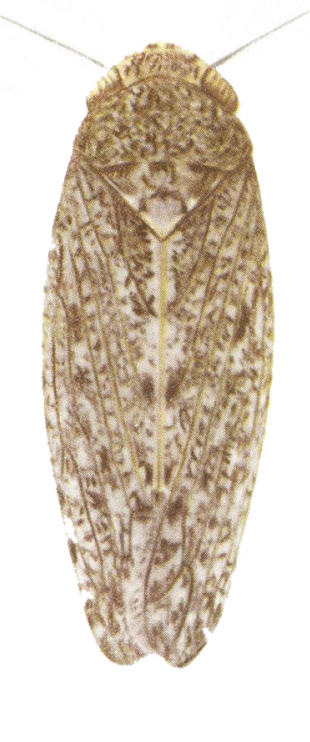

C

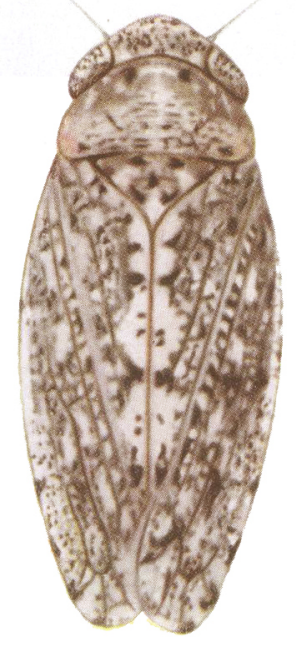

G

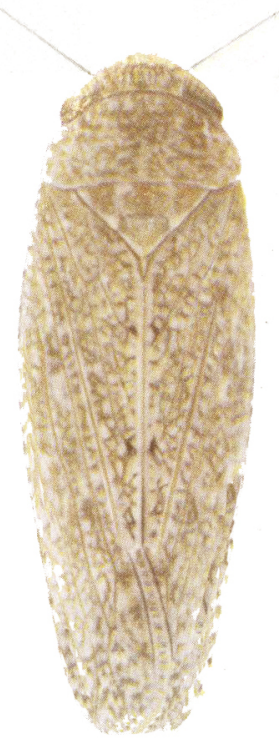

$D$

Plate 3 - 4 , Male, $B$, female Phlepsius apertinus Osborn and Lathrop: $C$, male, $D$, female Texananus spatulatus Van Duzee; $E$, male, $F$, female Texananus oregonus Ball; $G$, male, $H$, female Texananus pergradus DeLong. 